\title{
Carbonate and organic matter sedimentation and isotopic signatures in Lake Chungará, Chilean Altiplano, during the last 12.3 kyr
}

\author{
Juan José Pueyo ${ }^{\mathrm{a}, *}$, Alberto Sáez ${ }^{\mathrm{a}}$, Santiago Giralt ${ }^{\mathrm{b}}$, Blas L. Valero-Garcés ${ }^{\mathrm{c}}$, Ana Moreno ${ }^{\mathrm{c}}$, Roberto Bao ${ }^{\mathrm{d}}$, \\ Antje Schwalb ${ }^{\mathrm{e}}$, Christian Herrera ${ }^{\mathrm{f}}$, Bogumila Klosowska ${ }^{\mathrm{b}}$, Conxita Taberner ${ }^{\mathrm{g}}$ \\ a Universitat de Barcelona, Facultat de Geología, c/Martí Franquès, s/n, 08028 Barcelona, Spain \\ b Institut de Ciencies de la Terra 'Jaume Almera', CSIC, c/Solé Sabarís, s/n, 08028 Barcelona, Spain \\ c Instituto Pirenaico de Ecología, CSIC, Avda. Montañana, 1000, 50192 Zaragoza, Spain \\ ${ }^{\mathrm{d}}$ Universidade de A Coruña, Facultade de Ciencias, Campus da Zapateira s/n, 15071 A Coruña, Spain \\ e Technische Universität Braunschweig, Institut fur Umweltgeologie, Langer Kamp 19c, 38106 Braunschweig, Germany \\ ${ }^{\mathrm{f}}$ Universidad Católica del Norte, Avda. Angamos 0610, Antofagasta, Chile \\ ${ }^{g}$ Shell International Exploration and Production B.V., 2288 GS Rijswijk (ZH), Netherland
}

\section{A R T I C L E I N F O}

\section{Article history:}

Received 22 July 2010

Received in revised form 15 May 2011

Accepted 22 May 2011

Available online 30 May 2011

\section{Keywords:}

Carbonate precipitation

DIC speciation

Methanogenesis

Paleoenvironmental changes

Holocene record

Andean Altiplano

\begin{abstract}
A B S T R A C T
Sediments in lakes in the Andean volcanic setting are often made up of diatomaceous ooze together with volcaniclastics and small amounts of carbonates. Despite their scarcity, carbonates along with organic matter provide significant paleoenvironmental information about lake systems. This study focuses on the carbonates in Lake Chungará, their morphologies, distribution and origin deduced from the isotopic markers. These markers reflected changes in the water and the biomass between the onset of the Holocene and around $9.6 \mathrm{cal}$ kyr BP. These changes are marked by general increases in TOC, TN, and TN- $\delta^{15} \mathrm{~N}_{\mathrm{AIR}}$, and by fluctuating values of TOC- $\delta{ }^{13} C_{\text {VPDB }}$ in its sediments and are probably related to major shifts in the lake surface/volume associated with rises in lake level. An increase in salinity around $10 \mathrm{cal} \mathrm{kyr} \mathrm{BP} \mathrm{is} \mathrm{thought} \mathrm{to} \mathrm{be} \mathrm{linked} \mathrm{to} \mathrm{a} \mathrm{short} \mathrm{dry} \mathrm{period,}$ giving rise to the onset of carbonate production. The mid-Holocene arid period between 7.3 and $3.5 \mathrm{cal} \mathrm{ka} \mathrm{BP}$, with a maximum of aridity around $6.0 \mathrm{cal} \mathrm{kyr} \mathrm{BP}$, was deduced from $\delta^{18} \mathrm{O}_{\mathrm{VPDB}}$ values in the endogenic carbonates. These results match the reconstructions in Lake Titicaca based on benthic diatoms and paleoshore levels.

Offshore sediments mainly consist of a diatomaceous ooze, laminated in the lower half (Unit 1 ), and bandedmassive with tephra layers in the upper half of the sequence (Unit 2). TOC- ${ }^{13} \mathrm{C}_{\mathrm{VPDB}}$ and the $\mathrm{C} / \mathrm{N}$ ratio confirm that phytoplankton was the main source of organic matter in these sediments. Shallower sediments (units 3 to 5) developed in platform and littoral settings, providing evidence of subaqueous macrophytes and, to a lesser extent, land plants. Carbonate content ranges between 0.1 and $6 \mathrm{wt}$ \% in offshore settings (30 to $40 \mathrm{~m}$ water depth) and reaches the maximum values in the lower part of Unit 2. Carbonate minerals (low magnesium calcite and minor amounts of high magnesium calcite and aragonite) are scarce and are arranged in mm-thick layers, commonly forming $\mathrm{cm}$-thick levels or bioclasts. Carbonate layers are made up of euhedral-to-subhedral spindle-shaped calcite crystals and, to a lesser extent, aragonite needles, all in the $\mu \mathrm{m}$ range. Aragonite spheroids coexist in littoral sediments with other carbonate shapes and charophyte remains, where carbonate reaches locally up to $20 \mathrm{wt} . \% . \mathrm{CO}_{2}$ photosynthetic depletions related to seasonal phytoplankton blooms were responsible for the high frequency deposition of mm-thick carbonate layers. The average values for $\delta^{13} C_{\mathrm{VPDB}}$ in lake water, plankton and sediments of Lake Chungará (as organic matter or as carbonate) are around $15 \%$ higher than commonly reported values in other lakes. This ${ }^{13} \mathrm{C}$ enrichment is attributed to carbon assimilation from a DIC affected by methanogenesis, in which $\mathrm{HCO}_{3}^{-}$is the dominant species. The $\delta^{13} \mathrm{CVPDB}_{\mathrm{VPB}}$ and $\delta^{18} \mathrm{O}_{\mathrm{VPDB}}$ variations and their covariation in endogenic carbonates suggest that lake water volume and lake level increased along the Holocene.
\end{abstract}

(c) 2011 Elsevier B.V. All rights reserved.

\footnotetext{
* Corresponding author. Tel.: + 34 934021401; fax: + 34934021340. E-mail address: jjpueyo@ub.edu (J.J. Pueyo).
}

\section{Introduction}

Carbonates in lacustrine sediments provide paleoenvironmental information about biological and hydrological changes through time. Physicochemical changes in lake water cause biota modifications that are frequently associated with carbonate deposition. Moreover, lacustrine 
carbonates contain mineralogical and geochemical markers, such as the isotopic composition of carbon and oxygen, furnishing quantitative data for paleoclimatic and paleohydrological approaches (Li and Ku, 1997; Utrilla et al., 1998; Valero-Garcés et al., 1999a; Ito, 2001; Shapley et al., 2005). Carbonate $\delta^{18} \mathrm{O}_{\mathrm{VPDB}}$ is dependent on temperature and on water $\delta^{18} \mathrm{O}_{\text {VSMOW }}$ (Nelson and Smith, 1966). Shells of benthic organisms formed below the thermocline reflect changes in the isotopic composition of lake water whereas shells of planktonic organisms are mainly affected by variations in water temperature, both having positive offsets between 0 and $+2 \%$ o (von Grafenstein et al., 1999). Carbonate $\delta^{13} C_{\text {VPDB }}$ is related to carbon sources, biomass and biological processes in the catchment and DIC residence time in lake water (McKenzie, 1985; Schwalb, 2003). The main controls of DIC $-\delta^{13} C_{\text {VPDB }}$ in lakes are groundwater and surface water inputs, remains of organic matter from the catchment area (reaching $\delta^{13} \mathrm{C}_{\mathrm{VPDB}}-25 \%$ in the case of land plants), dissolution of older carbonate ( 0 to $+2 \%$ in marine carbonates), equilibration with atmospheric $\mathrm{CO}_{2}$, and ${ }^{12} \mathrm{C}$ selective uptake by aquatic plants during photosynthesis.

Organic matter in recent lake sediments preserves its original $\delta^{13} \mathrm{C}$, $\delta{ }^{15} \mathrm{~N}$ and $\mathrm{C} / \mathrm{N}$ values practically without change for thousands of years (Meyers, 1994). This is essential for recognizing environmental signatures and limnological changes recorded in lacustrine sediments. Organic matter provenance and mixing patterns are well recognized because lacustrine algae (and plankton) have lower $\mathrm{C} / \mathrm{N}$ values than cellulosic land plants. Moreover, the different photosynthetic types of plants can be recognized by their specific $\delta^{13} \mathrm{C}$ signatures (Meyers, 1994; Sifeddine et al., 2004). $\delta^{15} \mathrm{~N}$ provides information about contributions of algae, aquatic macrophytes and land plants, and depends on whether nitrogen proceeds from $\mathrm{NO}_{3}^{-}\left(\delta^{15} \mathrm{~N}\right.$ typically in the range +7 to $+10 \%$ o) or directly from atmospheric $\mathrm{N}_{2}\left(\delta^{15} \mathrm{~N}\right.$ around $0 \%$ ). Meyers (2003) also used $\delta^{15} \mathrm{~N}$ as an indicator of primary productivity.

Carbonates are minor components of sediments deposited in silicadominated lakes that are often located in active volcanic settings. However, they may provide significant additional information about lake evolution. Diatom dominated lake sediments are common in the Andean Altiplano and have been studied as paleoenvironmental archives at different time scales (Servant-Vildary and Roux, 1990; Bao et al., 1999; Sáez et al., 1999; Sylvestre, 2002; Tapia et al., 2003; Sáez et al., 2007; Hernández et al., 2008, 2010). The present paper is focused on the Late Quaternary carbonate sedimentation in Lake Chungará (northern Chilean Altiplano). The lake is characterised by diatom-rich deposits, interbedding tephra layers, and a few carbonate-rich intervals. Earlier work on the Chungará sequence described the sedimentological evolution of the lake during the last $14 \mathrm{kyr}$ and distinguished several lowstand lake stages, mostly based on the percentage of benthic diatoms (Sáez et al., 2007). A mid-Holocene dry episode has also been found using high resolution XRF-core scanner data (Moreno et al., 2007) and statistical analysis of mineralogical and chemical parameters (Giralt et al., 2008). Other approaches based on $\delta^{18} \mathrm{O}_{\text {vsmow }}$ from diatom frustules (Hernández et al., 2008, 2010) provide a paleohydrological reconstruction for the pure diatomaceous ooze intervals, and offer insights into processes generating the high frequency laminations of sediments. Furthermore, an isotopic study of bulk carbonate and organic matter in the short-core 93S from the NW bay of the lake (Fig. 1; Valero-Garcés et al., 2003) showed wide variations in composition and hydrology in the last centuries. Research has also been undertaken on geochemical signatures in endogenic carbonates in other lakes in the area (Laguna Seca, Miscanti and Negro Francisco) in an attempt to reconstruct climatic changes since the Last Glacial Maximum (Grosjean, 1994; Grosjean et al., 1997; Schwalb et al., 1999; Valero-Garcés et al., 1999b; Grosjean et al., 2001; Valero-Garcés et al., 2003; Theissen et al., 2008).

The main aim of this paper is to evaluate the paleoenvironmental information recorded in the isotopic markers in endogenic carbonates $\left(\delta^{13} \mathrm{C}_{\mathrm{VPDB}}\right.$ and $\left.\delta^{18} \mathrm{O}_{\mathrm{VPDB}}\right)$ and in the bulk organic matter $\left(\delta^{13} \mathrm{C}_{\mathrm{VPDB}}\right.$ and $\left.\delta{ }^{15} \mathrm{~N}_{\text {AIR }}\right)$ in the sedimentary record of Lake Chungará during the last
12.3 kyr. Although carbonates are discontinuous and although their amount is extremely low in the lowest part of the lacustrine sequence, our results highlight the advantage of a comprehensive study in an effort to better understand the geochemical signatures.

\section{Hydrological and geological settings}

Lake Chungará is located in the Chilean Altiplano ( $18^{\circ} 15 \mathrm{~S}, 69^{\circ} 09 \mathrm{~W}$, 4520 masl) at the base of the Holocene Parinacota volcano (Fig. 1). The lake was generated by a partial collapse of the earlier Parinacota stratocone that dammed the Paleo-Lauca River between 15 and $17 \mathrm{cal}$ kyr BP (Hora et al., 2007). The climate of the region is semi-arid (345$394 \mathrm{~mm} \mathrm{yr}^{-1}$ ) with an annual average temperature of $4.2^{\circ} \mathrm{C}$. Evaporation has been estimated to be about $1200 \mathrm{~mm} \mathrm{yr}^{-1}$ (Mladinic et al., 1987).

The lake has an irregular shape with a surface area of $22.5 \mathrm{~km}^{2}$ and a water volume of $426 \times 10^{6} \mathrm{~m}^{3}$. It has no surface outlets and the main inlet is the Chungará River (300-460 L s ${ }^{-1}$ ) (Fig. 1). Lake Chungará is $40 \mathrm{~m}$ deep with the present water level being the highest in its history (Risacher et al., 1999; Herrera et al., 2006) as evidenced by the absence of emerged paleoshores and terraces. The lake can be regarded as a superficially closed hydrological system owing to its water residence time of around 15 years (Herrera et al., 2006) and owing to the absence of surface outlets (Leng et al., 2005). The cold polymictic lake is today moderately alkaline ( $\mathrm{pH}$ between 8.99 and 9.30), well mixed ( $7.6 \mu \mathrm{L} \mathrm{L}^{-1} \mathrm{O}_{2}$ at $34 \mathrm{~m}$ deep), with moderate salinity $\left(1.3 \mathrm{~g} \mathrm{~L}^{-1} \mathrm{TDS}\right)$ and waters of the $\mathrm{Na}^{+}-\mathrm{Mg}^{2+}-\mathrm{HCO}_{3}^{-}-\mathrm{SO}_{4}^{2-}$ type. Concentrations of main solutes in $\mathrm{mg} \mathrm{L}^{-1}$ are $\mathrm{Na}^{+} 140, \mathrm{~K}^{+} 32, \mathrm{Ca}^{2+}$ $50, \mathrm{Mg}^{2+} 99, \mathrm{HCO}_{3}^{-} 450, \mathrm{Cl}^{-} 68$, and $\mathrm{SO}_{4}^{2-} 354$, and the molar $\mathrm{Mg} / \mathrm{Ca}$ ratio is around 3.26 (Risacher et al., 1999; Herrera et al., 2006; Sáez et al., 2007). In the last two decades, Lake Chungará has undergone marked inter-annual changes in the water level (around 2 to $3 \mathrm{~m}$ ) and significant oscillations in phytoplankton concentration (Dorador et al., 2003). The phytoplankton community is made up of a few species, including diatoms and Chlorophyceae that are dominant during cold and warm seasons, respectively. Dense macrophytic vegetation patches and microbial colonies occur in the littoral zone, also contributing to primary productivity (Dorador et al., 2003).

The seismic profiles indicate that the sedimentary succession is about $10 \mathrm{~m}$ thick and spans the last $12.3 \mathrm{kyr}$ (Giralt et al., 2008). The sediments are dominated by diatomaceous ooze with interbedded tephra layers in offshore zones, and peaty diatomaceous sediments in shallow marginal zones. A detailed study using seismic and core data enabled us to define five lithostratigraphic units (Fig. 2) (Sáez et al., 2007):

Unit 1. Shallow to deep offshore deposits

Subunit 1a. Finely laminated green diatomaceous ooze (12.39.8 cal kyr BP).

Subunit 1b. Laminated and massive brown diatomaceous ooze with carbonate-rich intervals (9.8-8.3 cal kyr BP).

Unit 2. Deep offshore deposits (with a shallow event).

Subunit 2a. Brown massive to banded diatomaceous ooze interbedding carbonate-rich intervals and tephra layers (ca 8.33.5 cal kyr B).

Subunit 2b. Dark grey-black, massive to banded diatomaceous ooze (ca 3.5 cal kyr BP - recent).

Unit 3. Shallow platform deposits ( $8.3 \mathrm{cal}$ kyr BP - present). This unit overlies Unit 1 deposits in the central lake areas, and changes laterally to offshore facies of Unit 2 towards the west, and to littoral facies of Unit 4 towards the east.

Unit 4. Shallow to very shallow littoral peaty, rich in charophyte remains (3.2 cal kyr BP - present).

Unit 5. Alluvial-deltaic deposits.

Three main components in the lake sediments have been identified using a combination of mineralogical and XRF-core scanner 

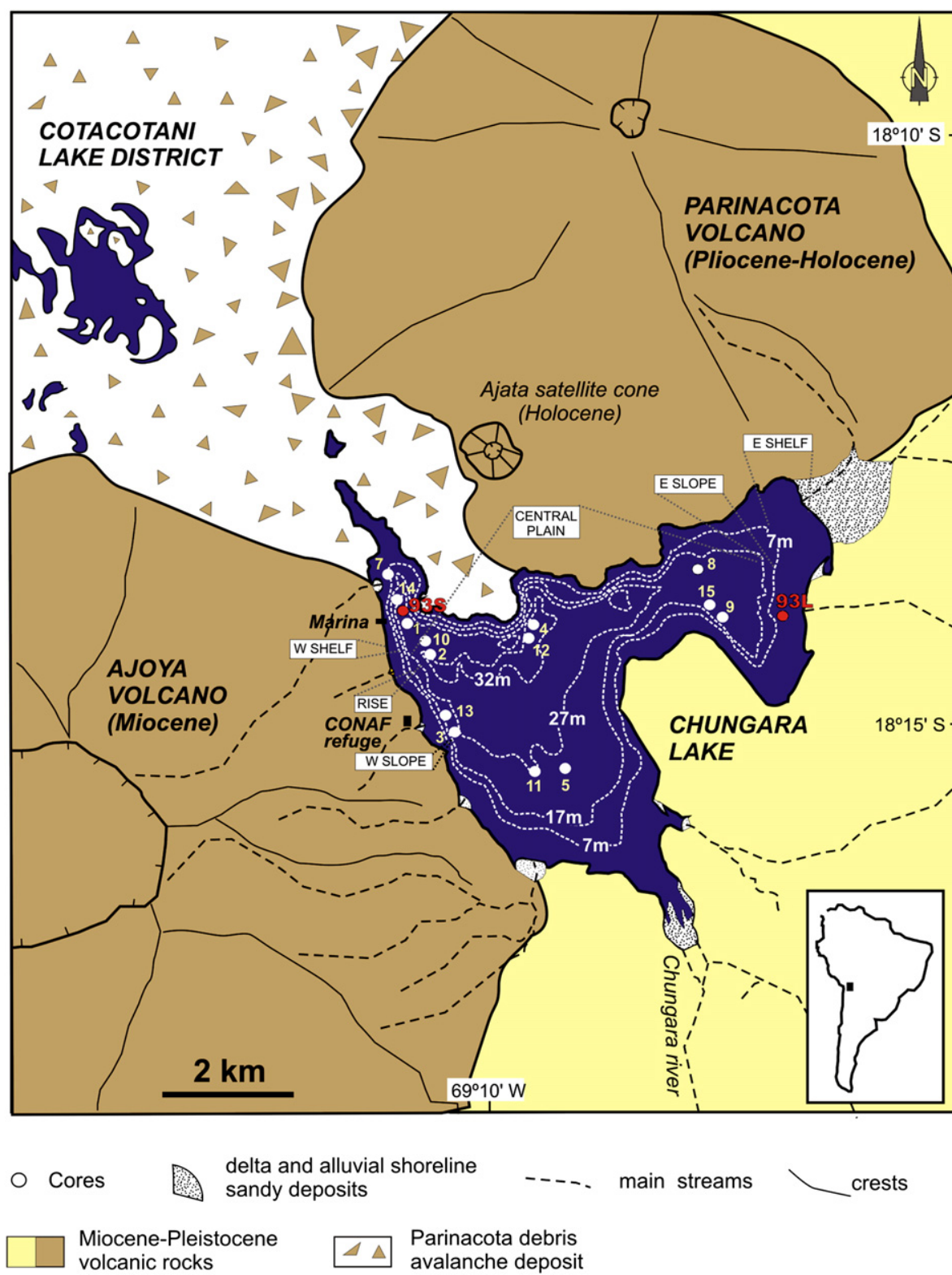

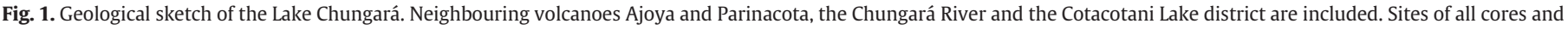
the lake-bottom topography and morphology are also indicated.

data (Moreno et al., 2007; Giralt et al., 2008): a) a biogenic component mainly derived from phytoplankton, b) volcanic material (ash layers) from the nearby Parinacota Volcano, and c) endogenic carbonates. Carbonate-rich intervals and layers occur in subunits 1b, 2a, 3 and 4.

\section{Materials and methods}

Lacustrine sediments were sampled from 15 Kullemberg cores, each up to $8 \mathrm{~m}$ long, recovered from Lake Chungará in November 2002 and stored at $4{ }^{\circ} \mathrm{C}$ (Sáez et al., 2007). Short gravity cores were also collected near the margins of the lake (cores 93L and 93S) and drag samples were taken near the sites of the large Kullemberg cores in order to obtain information about the first centimetres of sediment and the sediment-water interface.

Selected core sequences were sampled every $5 \mathrm{~cm}$, each sample being $1 \mathrm{~cm}$ thick, for carbonate studies, smear slides, and elemental and stable isotope geochemistry. Samples for ostracode valves were taken every $20 \mathrm{~cm}$. Carbonates were characterised by petrographic, mineralogical and geochemical analyses. A preliminary estimation of the morphology and amount of carbonates was made from the smear slides and was complemented by XRD and SEM-EDS analyses.

Samples for XRD were dried at $60{ }^{\circ} \mathrm{C}$ for $24 \mathrm{~h}$ and manually ground using an agate mill. The $\mathrm{X}$-ray diffractions revealed that most samples were composed of a crystalline and an amorphous fraction (mostly opal), characterised by the presence of a broad peak centred between 20 and $25^{\circ} 2 \theta$. The identification and quantification of the main mineralogical species present in the crystalline fraction were carried out following a standard procedure (Chung, 1974). The amorphous fraction was quantified against artificial standards obtained by mixing pure diatomaceous ooze with increasing amounts of calcite.

A morphological description using a Jeol JSM-840 SEM-EDS and a Hitachi H-4100FE field emission SEM was made on selected samples. Owing to the high water content, samples were dried in two steps: first, most of the water was eliminated by capillarity using filter paper, and second, samples were freeze-dried and vacuum-stored prior to carbon coating. Secondary and backscattered electron images and $\mathrm{X}$-ray emission spectra were used systematically to characterise the components. 


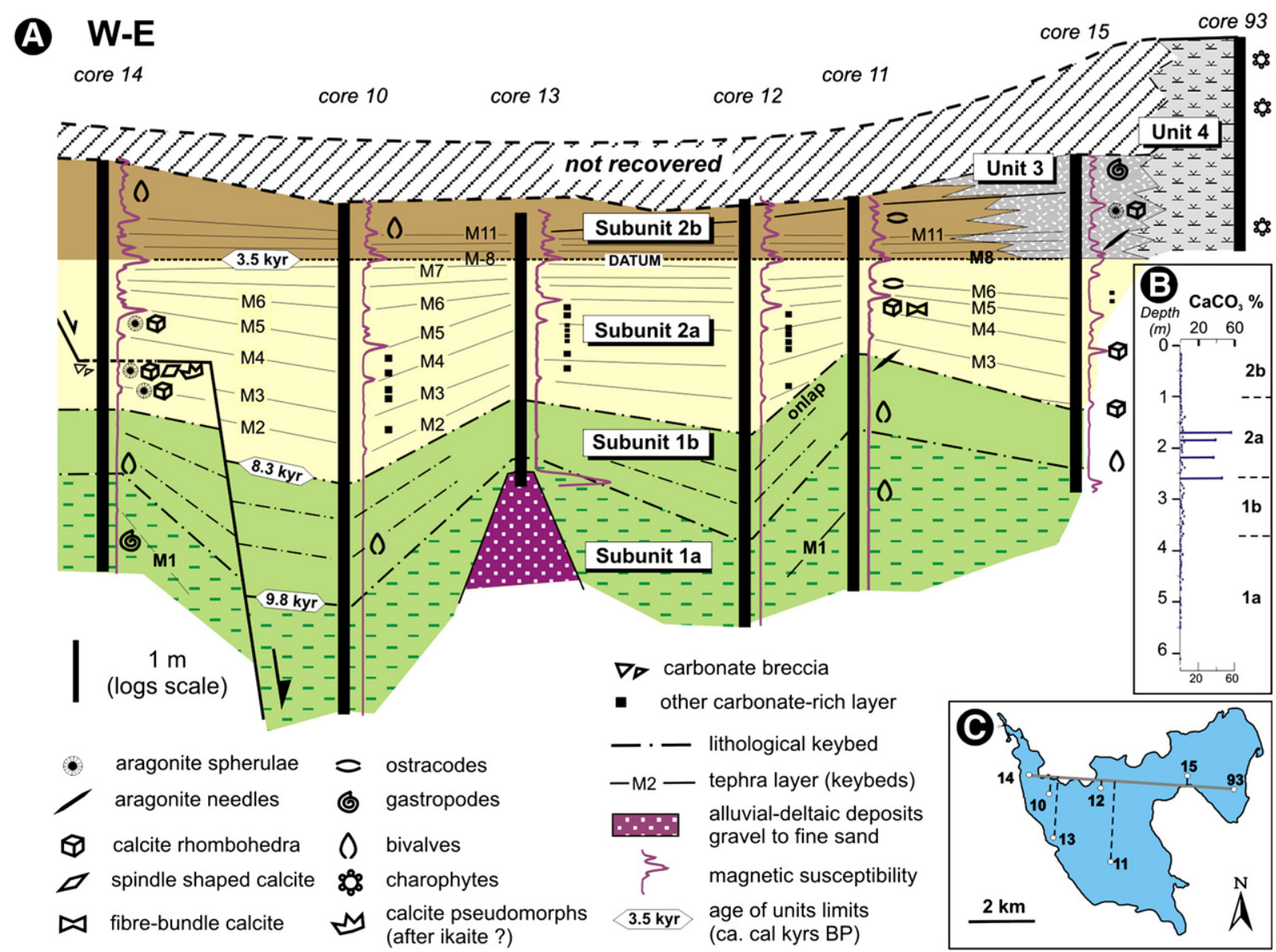

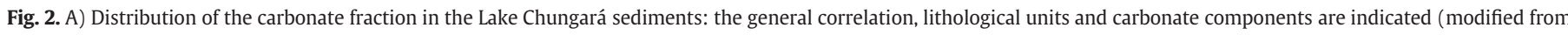

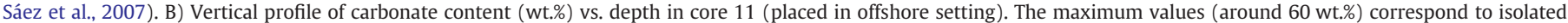
carbonate layer. C) Core sites in Lake Chungará and the W-E transect shown in A.

Isotopic compositions $\left(\delta^{13} \mathrm{C}_{\mathrm{VPDB}}\right.$ and $\left.\delta^{18} \mathrm{O}_{\mathrm{VPDB}}\right)$ of the carbonates were determined following two procedures: a) Carbonate-rich levels were analysed using bulk samples (about $10 \mathrm{mg}$ ) cleaned from organic matter with a concentrated sodium hypochlorite solution. A classic offline method using phosphoric acid with a silver phosphate trap was used to eliminate sulphurous gas species that were present in small amounts. The carbonate content was quantified by XRD to determine the amount of sample to be processed. b) Bulk microsamples of sediment (with low content of endogenic carbonate) and microsamples (about $60 \mu \mathrm{g}$ ) of single carbonate components (Chara coatings, ostracode valves, isolated carbonate crystals) were analysed with a Kiel II online preparation device online connected to a MAT 252 IRMS. Analytical precisions (as $\sigma$ ) for $\delta^{13} \mathrm{C}_{\mathrm{VPDB}}$ and $\delta^{18} \mathrm{O}_{\mathrm{VPDB}}$ determinations were 0.03 and $0.06 \%$, respectively.

Isotopic composition DIC- $\delta{ }^{13} C_{\text {VPDB }}$ was determined from filtered $(0.45 \mu \mathrm{m})$ water samples. Inorganic species of carbon (DIC, dissolved inorganic carbon) were precipitated adding $\mathrm{BaCl}_{2}$ excess in a basic media. Purified $\mathrm{CO}_{2}$ was obtained from the precipitated Ba-carbonate in a conventional line using phosphoric acid. The amount of coprecipitated Ba-sulphate was previously estimated by XRD in order to define the sample weight for analysis. Analytical precision expressed as $\sigma$ was $0.03 \%$.

TOC (total organic carbon) and TIC (total inorganic carbon) in sediments and biomass samples were determined directly and after treatment at $400{ }^{\circ} \mathrm{C}$ in a Leco SC-144DR. TN (total nitrogen) was determined in a Variomax $\mathrm{C} / \mathrm{N}$ following the Dumas' method (Ma and Gutterson, 1970).

Isotopic compositions $\left(\delta^{13} \mathrm{C}_{\mathrm{VPDB}}\right.$ and $\left.\delta^{15} \mathrm{~N}_{\mathrm{AIR}}\right)$ of organic matter were measured in sediments and biomass. Sediments were treated with diluted $(1: 4) \mathrm{HCl}$ to eliminate minor amounts of carbonate. Plankton was separated using silica filters $(0.45 \mu \mathrm{m})$. An elemental analyser, connected on line to a continuous flux Finnigan MAT Delta Plus IRMS, was used to determine $\delta^{13} \mathrm{C}_{\mathrm{VPDB}}$ and $\delta^{15} \mathrm{~N}_{\text {AIR. Analytical }}$ precision (as $\sigma$ ) for $\delta^{13} \mathrm{C}_{\mathrm{VPDB}}$ and $\delta^{15} \mathrm{~N}_{\mathrm{AIR}}$ determinations was $0.2 \%$, in both cases.

Isotopic compositions $\left(\delta^{18} \mathrm{O}_{\mathrm{VSMOW}}\right.$ and $\left.\delta \mathrm{D}_{\mathrm{VSMOW}}\right)$ of waters were also analysed by $\mathrm{CO}_{2}$ and $\mathrm{H}_{2}$ equilibration (using Pt as catalyser) in an automatic unit connected online to a double inlet Finnigan MAT Delta S IRMS. Analytical precision expressed as $\sigma$ was 0.2 and $1.5 \%$, respectively.

Isotopic standards used as reference were NBS-19 for carbonate $\delta^{13} C_{\text {VPDB }}$ and $\delta^{18} \mathrm{O}_{\text {VPDB }}$ and for water DIC- $\delta^{13} C_{\text {VPDB }}$; IAEA-N1, IAEA-N2, IAEA-NO3 and USGS-40 for $\delta^{15} \mathrm{~N}_{\mathrm{AIR}}$ and IAEA-CH6, IAEA-CH7 and USGS-40 for $\delta^{13} C_{\text {VPDB }}$ in organic matter; and VSMOW, SLAP and GISP for $\delta D_{\text {VSMow }}$ and $\delta^{18} \mathrm{O}_{\text {VSMOw }}$ in water samples.

The chronological model of Lake Chungara was based on 17 radiocarbonic AMS dates and on one ${ }^{238} \mathrm{U} /{ }^{230} \mathrm{Th}$ date (Giralt et al., 2008). The present day reservoir effect of the lake water was determined by dating the dissolved inorganic carbon (DIC) present in the surface lake water, and an apparent age of $2320 \pm 20$ radiocarbon years BP was obtained. This apparent reservoir effect age was corrected to offset the contamination of the thermonuclear tests carried out in the 1950s and 1960s (see Giralt et al., 2008 for further details). The calibration of the radiocarbon dates was performed using the CALIB 5.02 software and the INTCAL98 curve (Stuiver et al., 1998; Reimer et al., 2004). The software described in Heegaard et al. (2005) was employed to construct a reliable age-depth model, furnishing a corrected age for each calibrated date. 


\section{Results}

\subsection{Carbonate types}

A detailed petrographic study of the carbonates in Lake Chungará allowed the identification of several occurrences (Fig. 3):

\subsubsection{Euhedral to subhedral calcite crystals}

Crystals may show flat faces but commonly display a fibrous inner structure with fibres (approximately $1 \mu \mathrm{m}$ thick) arranged in the [001] direction (Fig. 3A). Only in a very few cases was high magnesium calcite observed. Calcite crystals display euhedral, spindle-shaped, and fibrebundle (Fig. 3B) morphologies, the last two shapes being predominant. Crystal sizes vary from $6 \times 10$ to $80 \times 200 \mu \mathrm{m}$ with the most common sizes ranging between $10 \times 30$ and $50 \times 80 \mu \mathrm{m}$. Subunit $2 \mathrm{a}$ has the highest numbers of calcite crystals, but calcite already occurs at the top of subunit 1b. Subunits 1a (the oldest lacustrine sediments), 2b, 3 and 4 have very low endogenic carbonate contents. Calcite crystals are scattered among other components (diatoms and siliciclastics) or are concentrated forming white mm-thick levels of almost pure calcite. Similar morphologies in calcite (and high-Mg calcite) have been extensively described in the literature (Fernández-Díaz et al., 1996; González-Muñoz et al., 2000; Braissant et al., 2003; Jiménez-López et al., 2003). The origin of these crystals is attributed to biologically induced precipitation in the epilimnion (Robbins and Blackwelder, 1992; Thompson et al., 1997).

\subsubsection{Needle-shaped aragonite crystals}

Some calcium carbonate-rich white layers (mm-thick; see cores 11 and 15; Fig. 2) are scattered in the sedimentary sequence and are made up of aragonite needle cumulates. Aragonite needles are crystals elongated after [001], commonly around $2 \times 10 \mu \mathrm{m}$ in size (Fig. 3C). Aragonite needles have been described in the literature and are related to whitings. They are also produced by calcareous algae and

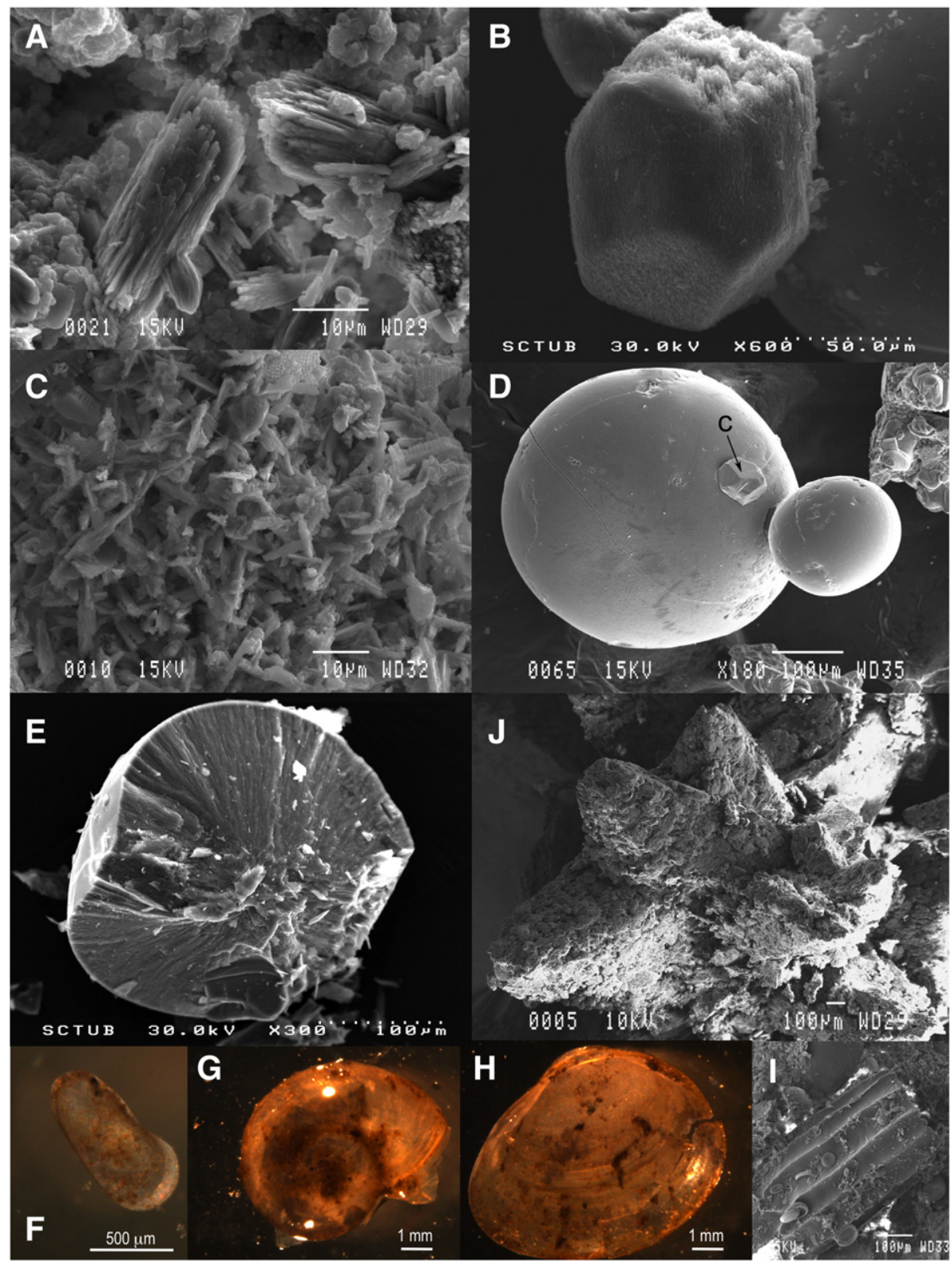

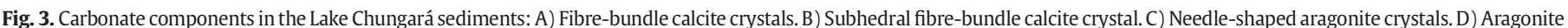

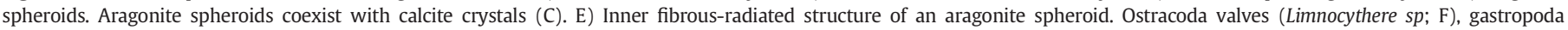

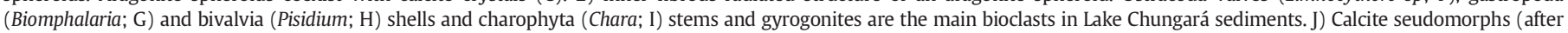
ikaite?) in core 14. 
microorganisms in marine and lacustrine environments (Lowenstam, 1955; Lowenstam and Epstein, 1956; Macintyre and Reid, 1992; Pedone and Folk, 1996), or precipitated experimentally (Callame and Dupuis, 1972; Zhou and Zheng, 2003).

\subsubsection{Aragonite spheroids}

Aragonite is also present as spheroids (Fig. 3D) commonly mixed with calcite crystals. Spheroids display variable diameters between 70 and $400 \mu \mathrm{m}$ and an inner fibrous-radiated structure (Fig. 3E) with radial fibres of aragonite about $0.5 \mu \mathrm{m}$ thick. Aragonite spheroids are very compact and are yellowish in colour with a pearl-like aspect. Spheroids of aragonite and other $\mathrm{CaCO}_{3}$ minerals (calcite, vaterite, and nesquehonite) have been precipitated under experimental conditions (Bischoff and Fyfe, 1968; Suess and Fütterer, 1972; Fernández-Díaz et al., 1996; Zhou and Zheng, 2003; Wu et al., 2008; Xiang et al., 2008) and have been described in marine and lacustrine environments (Monaghan and Lytle, 1956; Oppenheimer, 1961; Giralt et al., 2001).

\subsubsection{Bioclasts}

Calcareous skeletal components consist of ostracode valves (Limnocythere sp.; Fig. 3F), gastropod (Biomphalaria; Fig. 3G) and bivalve (Pisidium; Fig. 3H) shells and corticated charophyte stems (Chara sp.) (Fig. 3I). Ostracode, gastropod and bivalve remains are distributed in varying amounts throughout the entire sequence. Charophyte stems and gyrogonites are restricted to littoral sites. Bivalve shells and ostracode valves are composed of low-Mg calcite, and gastropod shells of aragonite. Charophyte stems commonly consist of low- and sometimes high-Mg calcite.

\subsubsection{Calcite cement}

Calcite cements that trap other components and replace previous minerals are 1 to $2 \mathrm{~mm}$ in size (Fig. 3J), and were found in core 15 . Carbonate cement shows grain sizes from 20 to $50 \mu \mathrm{m}$. Some of these pseudomorphs resembled those described by Grosjean (1994) in sediments from Laguna Lejía and were interpreted as calcite pseudomorphs versus ikaite.

\subsection{Carbonate distribution}

Carbonate displays a very heterogeneous distribution through the sequence and along an offshore-littoral transect (Fig. 2A and B). Carbonate bioclasts are scattered throughout the sequence, being more abundant in the dark green levels (rich in green algae, $\mathrm{C}$ facies in Sáez et al., 2007) and almost absent in the finely laminated diatomaceous ooze (A facies) of subunit 1a. Calcite crystals and aragonite needles and spheroids are commonly concentrated in white to grey thin layers. These layers are present in the entire series but frequently form discrete carbonate-rich intervals in subunit $1 \mathrm{~b}$ (B facies) and mainly in subunit 2a.

The shallow to deep offshore deposits of Unit 1 are poor in carbonate. The lowest part (subunit 1a), which consists of a finely laminated green diatomaceous ooze, is practically devoid of carbonate crystals and ostracode remains $\left(0.15 \mathrm{wt} . \% \mathrm{CaCO}_{3}\right)$. The only carbonates are shells of gastropods and bivalves. The upper part of the unit (subunit 1b), which is made up of a laminated and massive brown diatomaceous ooze, contains some carbonate-rich cm-thick intervals (2.25 wt.\% $\mathrm{CaCO}_{3}$ ) composed of mm-thick carbonate layers of calcite (mostly) or aragonite. Euhedral, $50 \mu \mathrm{m}$ long, calcite crystals and acicular aragonite crystals, $10 \mu \mathrm{m}$ long and $2 \mu \mathrm{m}$ wide, are scattered in the diatomaceous ooze. The upper part of subunit $1 \mathrm{~b}$ also contains whole and fragmented shells of bivalves and gastropods, but ostracode valves are absent. The interval from 2.56 to $2.66 \mathrm{~m}$, at the top of Unit 1 in core 11, includes two carbonate layers.

The deep offshore deposits of Unit 2 contain higher amounts of carbonate than unit 1 . The lower part (subunit 2a) is formed by brown massive diatomaceous ooze and tephras and includes some $\mathrm{cm}$-thick carbonate-rich levels, and ostracode, bivalve and gastropod remains. Carbonate-rich levels account for up to $5 \%$ of the total thickness of subunit $2 \mathrm{a}$ (reaching around 6 wt. $\% \mathrm{CaCO}_{3}$ ) and are mostly concentrated in the lower half of the unit. Many levels are bunches of discrete whitish to pinkish mm-thick layers that are composed of calcite, minor amounts of high magnesium calcite and aragonite, and some traces of dolomite. The proportion of the carbonate mineral varies in the same carbonate-rich level throughout the basin. A change from calcite to aragonite was detected (with an accuracy around $1 \mathrm{~cm}$ ) along several carbonate levels between cores located about $4 \mathrm{~km}$ from each other at water depths between 10 and $25 \mathrm{~m}$ (Fig. 4). Calcite-rich levels are composed of fibre-bundle crystals (Fig. 3A), spindle-shaped aggregates, rice-shaped crystals and dumbbells (10 to $200 \mu \mathrm{m}$ long and 6 to $80 \mu \mathrm{m}$ wide), euhedral crystals (50 to $100 \mu \mathrm{m}$ in size) and irregular aragonite spheroids ( 70 to $140 \mu \mathrm{m}$ diameter). Aragonite-rich levels show needle-shaped crystals $10 \mu \mathrm{m}$ long and 1 to $3 \mu \mathrm{m}$ wide. A carbonate-breccia recorded as a unique layer in core 14 (279 to $321 \mathrm{~cm}$ depth) with an erosive contact with the underlying sediments is composed of angular shaped, cm-thick carbonate clasts in a diatomaceous brown matrix. The upper part of the unit (subunit $2 b$, $3.55 \mathrm{cal}$ kyr BP to recent) is formed by a massive dark grey diatomaceous ooze practically devoid of endogenic carbonate crystals ( 0.24 wt.\% $\mathrm{CaCO}_{3}$ for total endogenic carbonate). Ostracode valves are relatively abundant. Bivalve and gastropod shells are also present in some levels. The chlorophycean Botryococcus braunii records the highest concentration in the whole sequence, which is consistent with an offshore deposition around 30-40 $\mathrm{m}$ water depth for this unit (Sáez et al., 2007).

Shallow platform deposits of Unit 3 are composed of dark green diatomaceous ooze with abundant macrophyte remains and tephra levels. These sediments display gastropod and bivalve shells in discrete, $\mathrm{mm}$ - to $\mathrm{cm}$-thick layers and carbonate-rich levels equivalent to the ones described in subunit $2 \mathrm{a}$.

Shallow to very shallow littoral deposits of Unit 4 (less than $5 \mathrm{~m}$ depth) mainly consist of macrophytic peaty deposits rich in diatoms, some intercalated fine-grained tephra layers and carbonate-rich, charophyte-dominated deposits with gastropod and bivalve shells. Carbonates consist of calcite and Mg-calcite, and reach up to $25 \mathrm{wt} . \%$ in charophyte-rich levels. Carbonate components are mainly constituted by mineralized intercellular areas and calcite-covered charophyte stems. Ostracode and gastropod remains are also abundant.

As regards the paleogeographic distribution, carbonates predominate in littoral settings. Apart from core 93L, located on the eastern lacustrine shelf (Fig. 1), cores 14 and 15 (westwards and towards the eastern platform, respectively) contain more carbonate and its crystals are larger. Thus, the only carbonates recorded in core 11 are calcite (as fibre-bundle crystals) and aragonite needles. Aragonite spheroids are only present in littoral settings, being abundant in core 14 and, to a lesser extent, in core 15 . Short-core $93 \mathrm{~S}$ retrieved in the western sub-basin at $19 \mathrm{~m}$ water depth describes the most recent centuries of sedimentation in off shore settings in Lake Chungará. Sediments are composed of black, diatomaceous and organic-rich (up to $25 \%$ OM) laminated mud with a low carbonate content (6-8\%). Two cm-thick levels show a high carbonate content (up to 50\%) composed of euhedral calcite crystals and charophyte fragments (Valero-Garcés et al., 2003).

\subsection{Isotopic markers of Lake Chungará}

\subsubsection{Recent water isotopic compositions ( $\delta D_{V S M O W}, \delta^{18} \mathrm{O}_{V S M O W}$ and DIC $-\delta^{13} C_{\text {VPDB }}$ )}

The water in Lake Chungará is significantly heavier than the water inputs (Chungará River, springs) and the rain and snow in the Lauca Basin (Herrera et al., 2006). All the samples of the lake surface and deep lake waters (November 2002 survey) display homogeneous values in $\delta D_{\text {VSMow }}(-43 \%$ in average, ranging from -46 to $-40 \%$ o) 


$\begin{array}{cccc}\text { core 11 } & \text { core 14 } & \text { core 10 } & \text { core 15 } \\ \delta^{13} \mathrm{C} \quad \delta^{18} \mathrm{O} & \delta^{13} \mathrm{C} \delta^{18} \mathrm{O} & \delta^{13} \mathrm{C} \delta^{18} \mathrm{O} & \delta^{13} \mathrm{C} \delta^{18} \mathrm{O}\end{array}$

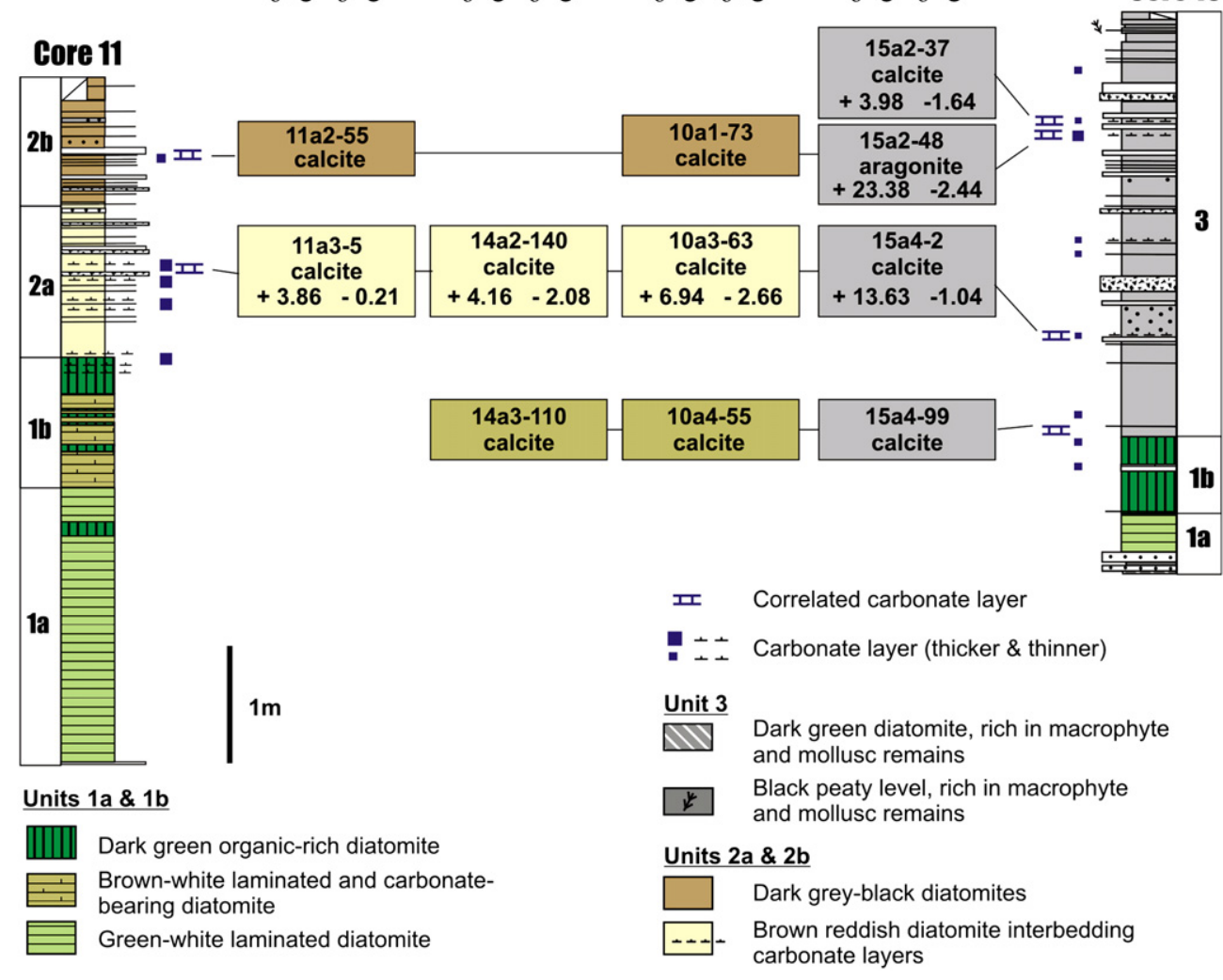

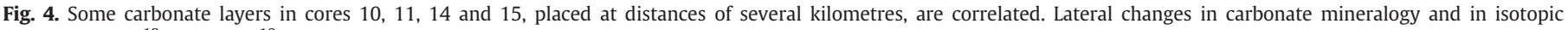

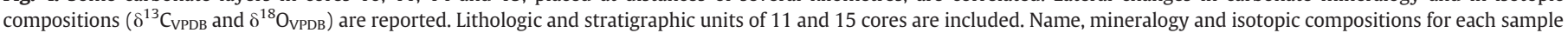
are shown. Samples 15a2-48 and 15a4-2 (in core 15) showing very high $\delta^{13} \mathrm{C}_{\mathrm{VPDB}}$ values reflect methanogenic fermentation.

and $\delta^{18} \mathrm{O}_{\text {VSMow }}(-1.6 \%$ in average, -1.76 to $-1.49 \%$ in range), showing $\delta \mathrm{D}_{\text {VSMOW }}$ and $\delta^{18} \mathrm{O}_{\text {VSMow }}$ enrichments of +80 and $+15 \%$ with respect to average meteoric waters in the area. Values from an earlier survey (January 2001) show similar values for Chungará lake waters.

Isotopic composition of inorganic carbon species dissolved in lake water (DIC- $\delta^{13} \mathrm{C}_{\mathrm{VPDB}}$ ) is also significantly heavier than the water inputs (Table 1). Fifteen samples of lake water, 1 sample from the Chungará River and 5 samples from the springs around the lake were also analysed. The DIC- $\delta{ }^{13} \mathrm{C}_{\mathrm{VPDB}}$ average values are $+4.7 \%$ (range between +3.21 and +5.97 ) for Chungará lake water, $-1.1 \%$ o for Chungará River and $-7.14 \%$ o $(-10.14$ to $-2.69 \%$ ) for the springs.

4.3.2. Recent and old organic matter $C / N$ atomic ratio and isotopic compositions ( $\delta^{13} C_{V P D B}$ and $\delta^{15} N_{A I R}$ )

Land plant samples in the catchment and aquatic plants, plankton and sediments in the lake were analysed for $\mathrm{C} / \mathrm{N}, \delta{ }^{13} \mathrm{C}_{\mathrm{VPDB}}$ and $\delta{ }^{15} \mathrm{~N}_{\mathrm{AIR}}$ (Table 2; Fig. 5) to obtain information about biomass provenances in the lake. The $\mathrm{C} / \mathrm{N}$ ratio of recent biomass in Lake Chungará yields values between 40 and 80 for land plants, between 4 and 25 for aquatic plants, and around 8.7 for plankton. Carbon isotopic composition ranges from values around $-25 \%$ o for land plants, $-6 \%$ for aquatic plants (between -10 and $-4 \%$ ), and around $-13 \%$ or plankton. Nitrogen isotopic composition ranges between -1 and $+5 \%$ ofor land plants, around $0 \%$ 。 for cyanobacterial mats, and between 0 and $+12 \%$ or aquatic plants.

Recent sediments ( $2 \mathrm{~cm}$ below the water-sediment interface) from short cores, and core 15 show $\mathrm{C} / \mathrm{N}$ values between 12 and $14, \delta^{13} \mathrm{C}_{\mathrm{VPDB}}$ values around $-15 \%$ and $\delta{ }^{15} \mathrm{~N}_{\text {AIR }}$ between +5 and $+7 \%$. Recent offshore sediments from short-core 93S (Valero-Garcés et al., 2003) show $\delta^{13} C_{\text {VPDB }}$ values between -14 and $-20 \%$. Older sediments from core 15 show $\mathrm{C} / \mathrm{N}$ ratios between 12 and $17, \delta^{13} \mathrm{C}_{\mathrm{VPDB}}$ around $-16 \%$, and $\delta{ }^{15} \mathrm{~N}_{\text {AIR }}$ from +4 to $+7 \%$ o close to the short-core values. Core 11 sediments display lower values of $\delta^{13} \mathrm{C}_{\mathrm{VPDB}}$ (between -16 and $-22 \%$ ), $\delta{ }^{15} \mathrm{~N}_{\mathrm{AIR}}$ between +10 and $+1 \%$, and $\mathrm{C} / \mathrm{N}$ values between 8 and 17 .

\subsubsection{Isotopic compositions ( $\delta^{13} C_{V P D B}$ and $\delta^{18} O_{V P D B}$ ) of carbonates}

Carbonates were selected from four cores $(11,14,15$ and 93L; Fig. 1). Endogenic carbonates from cores 11, 14 (in offshore areas of the lake) and 15 (on the eastern platform) consist of calcite crystals and aragonite spheroids and, in smaller amounts, needle-like aragonite. All these materials were analysed either as bulk samples (mixed with diatomaceous ooze) when separation of the carbonate fraction was not possible, or as individual components (calcite crystals, spheroids, and aragonite needles). Moreover, bivalve shells and ostracode valves were analysed in offshore core 11. Carbonate samples from core 93L, in the eastern shallow platform, which is dominated by Chara gyrogonites and stem incrustations, were also analysed.

Bulk samples containing endogenic carbonate crystals from cores 10, 11, 14, 15 and 93L, show varying isotopic compositions (Fig. 6A). Core 11 located in the central area of the lake (28 $\mathrm{m}$ deep) displays values of $\delta^{13} C_{\mathrm{VPDB}}$ between +3 and $+5 \%$, and $\delta^{18} \mathrm{O}_{\mathrm{VPDB}}$ ranging between -0.5 and $0 \%$. Core 14 , also in a deeper area $(27 \mathrm{~m}$, but close to the NW shore) shows higher $\delta^{13} \mathrm{C}_{\mathrm{VPDB}}$ values $(+3.5$ to $+6 \%$ ) and lower $\delta^{18} \mathrm{O}_{\mathrm{VPDB}}$ values $(-2$ to $0 \%$ ). Samples from core $93 \mathrm{~L}$ show even more clearly the shift to higher and lower values in both $\delta{ }^{13} \mathrm{C}_{\mathrm{VPDB}}(+7$ to $+11 \%$ ) and $\delta^{18} \mathrm{O}_{\mathrm{VPDB}}$ (and -4 to $0 \%$ ) at around $5 \mathrm{~m}$ depth. The available bulk samples from core 15 (Fig. 6A), which are located on the eastern platform at an intermediate depth of $24 \mathrm{~m}$, show the highest values of $\delta{ }^{13} \mathrm{C}_{\mathrm{VPDB}}$ (i.e.: $+14,+23 \%$ ) found in the lake. The bulk samples from recent off shore sediments show greater variation 
Table 1

Isotopic composition ( $\delta \mathrm{D}_{\mathrm{VSMOW}}, \delta^{18} \mathrm{O}_{\mathrm{VSMOW}}$ and DIC- $\delta{ }^{13} \mathrm{C}_{\mathrm{VPDB}}$ ) of surface waters and springs at Chungará-Cotacotani (November 2002 survey; Herrera et al., 2006).

\begin{tabular}{|c|c|c|c|c|}
\hline Sample & Site & $\delta \mathrm{D}$ & $\delta^{18} \mathrm{O}$ & $\delta^{13} \mathrm{C}$ DIC \\
\hline Choquelin & Rain 6-10-02 & -132.3 & $-19,40$ & \\
\hline RIO-1 & Chungará river & -113.1 & $-16,09$ & -1.15 \\
\hline MAN-1 & Spring Ajata & -105.9 & $-15,28$ & -6.86 \\
\hline MAN-2 & Spring CONAF & -121.9 & $-17,04$ & -8.97 \\
\hline MAN-3 & Spring & -116.6 & $-16,49$ & -7.04 \\
\hline MAN-4 & Spring basalt Parinacota & -112.1 & $-16,23$ & -2.69 \\
\hline MAN-5 & Spring N of Ajata & -121.7 & $-17,12$ & -10.14 \\
\hline CHU-1 & $\begin{array}{l}\text { Chungara lake, isolated } \\
\text { very shallow shore }\end{array}$ & -91.9 & $-11,81$ & -0.43 \\
\hline CHU-2 & Chungara lake, harbour & -44.4 & $-2,05$ & $+4,18$ \\
\hline CHUN-1A & Chungara lake & -42.0 & $-1,52$ & $+4,96$ \\
\hline CHUN-1B & Chungara lake & -42.6 & $-1,62$ & $+4,26$ \\
\hline CHUN-2A & Chungara lake & -39.9 & $-1,56$ & $+3,21$ \\
\hline CHUN-2B & Chungara lake & -43.4 & $-1,54$ & $+5,17$ \\
\hline CHUN-2C & Chungara lake & -43.4 & $-1,578$ & $+4,56$ \\
\hline CHUN-010 & Chungara lake & -44.0 & $-1,54$ & \\
\hline CHUN-011 & Chungara lake & -44.7 & $-1,58$ & $+4,62$ \\
\hline CHUN-013 & Chungara lake & & & $+3,86$ \\
\hline CHUN-014A & Chungara lake & -43.2 & $-1,53$ & $+5,52$ \\
\hline CHUN-014B & Chungara lake & -44.4 & $-1,58$ & $+5,34$ \\
\hline CHUN-015A & Chungara lake & -44.2 & $-1,49$ & $+5,43$ \\
\hline CHUN-015B & Chungara lake & -45.8 & $-1,61$ & $+3,55$ \\
\hline CHUN-016A & Chungara lake & -44.3 & $-1,49$ & $+5,97$ \\
\hline CHUN-016B & Chungara lake & -41.7 & $-1,76$ & $+3,68$ \\
\hline CHUN-017 & Chungara lake & -43.0 & $-1,74$ & $+5,52$ \\
\hline COT-1 & Cotacotani, Laguna verde & -12.3 & $+3,02$ & -7.43 \\
\hline COT-2 & Cotacotani, Laguna verde & -100.2 & $-12,82$ & -5.45 \\
\hline COT-3 & Cotacotani lake & -65.8 & $-5,20$ & $+4,67$ \\
\hline COT-4 & Cotacotani lake & -79.4 & $-7,93$ & -3.94 \\
\hline COT-5 & Cotacotani lake & -68.4 & $-7,23$ & $+2,13$ \\
\hline COT-6 & Cotacotani, isolated pool rich in m.o. & -52.0 & $-2,19$ & -6.65 \\
\hline COT-8 & Cotacotani, isolated pool near road & -9.6 & $+9,46$ & -2.88 \\
\hline
\end{tabular}

( +1 to $-13 \%$ for $\delta^{18} \mathrm{O}_{\mathrm{VPDB}}$ and +8 to $-25 \%$ for $\delta^{13} \mathrm{C}_{\mathrm{VPDB}}$; ValeroGarcés et al., 2003).

Apart from the bulk samples, microsamples of individual components (ostracode, gastropod and bivalve remains, calcite crystals, aragonite needles and spheroids; Table 3, Fig. 6A) were analysed in the same cores. Excluding charophyte stems from core $93 \mathrm{~L}, \delta^{13} \mathrm{C}_{\mathrm{VPDB}}$ and $\delta^{18} \mathrm{O}_{\mathrm{VPDB}}$ range from -2 to +6 and from -1 to $+4 \%$, respectively. As a rule, bivalve shells show widespread values and are always rather depleted in ${ }^{13} \mathrm{C}$ (about - 5\%) and enriched in ${ }^{18} \mathrm{O}$ (about $+3 \%$ ) with respect to crystals (calcite or aragonite), spheroids (aragonite) or ostracode remains. Ostracode valves analysed from core 11 display a pattern similar to that of the bulk samples $\left(\delta^{13} \mathrm{C}_{\mathrm{VPDB}}\right.$ between +1 and $+5 \%$, and $\delta^{18} \mathrm{O}_{\mathrm{VPDB}}$ between -0.5 and $+2 \%$ ). Aragonite and calcite crystals, and aragonite spheroids from cores 11 and 14 also show values similar to those of the bulk samples (Fig. 6A). Likewise, isolated Chara stems show the same isotopic dispersion as bulk samples (strongly dominated by Chara remains) from core 93L.

\section{Discussion}

\subsection{Origin of organic matter}

Organic matter in recent sediments in Lake Chungará (upper $2 \mathrm{~cm}$ of short-core samples) displays TOC- $\delta{ }^{13} \mathrm{C}_{\mathrm{VPDB}}$ values close to plankton $\left(-15\right.$ and $-13 \%$, respectively; Table 2, Fig. 5). These $\delta^{13} C_{\text {VPDB }}$ values are higher than those commonly attributed to plankton (Fig. 5B; Meyers, 1994, 2003) and are related to high values of TOC $-\delta^{13} C_{\mathrm{VPDB}}$ and $\delta^{13} \mathrm{C}_{\mathrm{VPDB}}$ of carbonates. They are also consistent with the $+4 \%$ DIC- $\delta{ }^{13} C_{\text {VPDB }}$ values measured in the recent lake water (about 20\%。 heavier) (Table 1). The high $\delta^{13} \mathrm{C}_{\mathrm{VPDB}}$ values along the whole carbon cycle in lakes (DIC, biomass, TOC in sediments and endogenic
Table 2

TOC, TN, and isotopic compositions $\left(\delta^{13} \mathrm{C}_{\mathrm{VPDB}}\right.$ and $\left.\delta^{15} \mathrm{~N}_{\mathrm{AIR}}\right)$ of recent biomass and the organic fraction in bulk sediments from cores 11,15 and short-core samples) from Lake Chungará. $\mathrm{C}$ and $\mathrm{N}$ concentrations in plankton biomass (using filters $>0.045 \mu \mathrm{m}$ ) are also indicated. $\mathrm{C} / \mathrm{N}$ is expressed as atomic ratio.

\begin{tabular}{lcrrrl}
\hline Sample & TOC $(\%)$ & \multicolumn{1}{c}{$\delta^{13} \mathrm{C}$} & TN $(\%)$ & $\delta^{15} \mathrm{~N}$ & $\mathrm{C} / \mathrm{N}$ \\
\hline Recent vegetal samples into the lake and the catchment & & & \\
1. Lor4 aquatic plant & 39.76 & -7.45 & 3.70 & $+4,28$ & 12,5 \\
2. Cianobacterial mats & 43.72 & -10.04 & 11.43 & $-0,25$ & 4,5 \\
3. Lor 8 Seca. Aquatic plant & 32.90 & -6.10 & 3.39 & $+9,26$ & 11,3 \\
4. Chungara lake. Aquatic plant & 31.36 & -11.33 & 2.10 & $+8,94$ & 17,4 \\
5. Chungara lake. Aquatic plant & 42.94 & -5.72 & 5.07 & $+11,74$ & 9.9 \\
6. Chungara lake. Terrestrial pt. & 33.35 & -26.24 & 0.92 & $+1,37$ & 42,2 \\
11. Chungara lake. Aquatic plant & 40.34 & -3.95 & 1.99 & $+10,93$ & 23,6 \\
7. Terrestrial plant. 'Paja brava' & 43.31 & -24.85 & 0.65 & $+4,04$ & 77,5 \\
8. Terrestrial plant. 'Llareta'. & 25.36 & -25.06 & 0.60 & $+1,07$ & 49,0 \\
9. Terrestrial plant. & 47.52 & -23.39 & 1.09 & $+1,80$ & 50,7 \\
10. Terrestrial plant. & 53.14 & -24.60 & 1.08 & $-0,65$ & 57,5 \\
& & & & & \\
Plankton samples & & & & & \\
Filter 1 & 22.9 & -13.3 & 3.11 & $+3,43$ & 8,6 \\
Filter 2 & 21.3 & -14.2 & 2.85 & $+5,32$ & 8,7 \\
Filter 3 & 43.6 & -11.6 & 5.46 & $+3,53$ & 9,3
\end{tabular}

$\mathrm{C}$ and $\mathrm{N}$ concentration in water (from plankton)

\begin{tabular}{|c|c|c|c|c|c|}
\hline Sample & \multicolumn{3}{|c|}{$\operatorname{mgC~L}{ }^{-1}$} & \multicolumn{2}{|c|}{$\mathrm{Mg} \mathrm{N} \mathrm{L}^{-1}$} \\
\hline Filter 1 & \multicolumn{2}{|r|}{2.04} & & \multicolumn{2}{|c|}{276.6} \\
\hline Filter 2 & \multicolumn{2}{|r|}{2.83} & & \multicolumn{2}{|c|}{379.7} \\
\hline Filter 3 & \multicolumn{2}{|r|}{10.26} & & \multicolumn{2}{|c|}{1284.2} \\
\hline \multicolumn{6}{|c|}{ Short-core samples } \\
\hline Sample & TOC (\%) & $\delta^{13} \mathrm{C}$ & $\mathrm{TN}(\%)$ & $\delta^{15} \mathrm{~N}$ & $\mathrm{C} / \mathrm{N}$ \\
\hline $1 \mathrm{~A} 1 \mathrm{M} 0-1 \mathrm{~cm}$ & 12.70 & -14.22 & 1.20 & $+6,02$ & 12,3 \\
\hline $8 \mathrm{~A} 1 \mathrm{M} 0-1 \mathrm{~cm}$ & 16.77 & -15.06 & 1.47 & $+5,35$ & 13,3 \\
\hline $9 \mathrm{~A} 1 \mathrm{M} 0-1 \mathrm{~cm}$ & 22.47 & -14.48 & 1.90 & $+5,03$ & 13,8 \\
\hline $10 \mathrm{~A} 1 \mathrm{M} 0-1 \mathrm{~cm}$ & 10.17 & -16.1 & 0.95 & $+6,23$ & 12,4 \\
\hline $11 \mathrm{~A} 1 \mathrm{M} 0-1 \mathrm{~cm}$ & 8.88 & -15.62 & 0.78 & $+5,51$ & 13,2 \\
\hline $12 \mathrm{~A} 1 \mathrm{M} 0-1 \mathrm{~cm}$ & 10.82 & -15.74 & 0.96 & $+5,76$ & 13,1 \\
\hline $13 \mathrm{~A} 1 \mathrm{M} 0-1 \mathrm{~cm}$ & 10.49 & -15.9 & 0.97 & $+6,18$ & 12,6 \\
\hline $14 \mathrm{~A} 1 \mathrm{M} 0-1 \mathrm{~cm}$ & 12.56 & -14.1 & 1.19 & $+5,29$ & 12,3 \\
\hline
\end{tabular}

Core 15

\begin{tabular}{llllll}
\hline Sample depth $(\mathrm{m})$ & TOC $(\%)$ & $\delta^{13} \mathrm{C}$ & $\mathrm{TN}(\%)$ & $\delta^{15} \mathrm{~N}$ & $\mathrm{C} / \mathrm{N}$ \\
\hline 0.08 & 0.44 & -15.0 & 0.04 & $+5,24$ & 12,3 \\
0.25 & 1.95 & -15.5 & 0.16 & $+4,64$ & 14,2 \\
0.43 & 18.04 & -16.4 & 1.42 & $+4,12$ & 14,9 \\
0.63 & 6.73 & -15.6 & 0.48 & $+4,96$ & 16,2 \\
1.01 & 12.21 & -16.1 & 0.94 & $+6,72$ & 15,2 \\
1.39 & 0.64 & -15.6 & 0.05 & $+6,45$ & 13,8
\end{tabular}

Core 11

\begin{tabular}{lllllll}
\hline Sample & $\begin{array}{l}\text { Depth } \\
(\mathrm{m})\end{array}$ & $\begin{array}{l}\text { TOC } \\
(\%)\end{array}$ & $\delta^{13} \mathrm{C}$ & $\begin{array}{l}\mathrm{TN} \\
(\%)\end{array}$ & $\delta^{15} \mathrm{~N}$ & $\mathrm{C} / \mathrm{N}$ \\
\hline Section 2. 1 & 0.16 & 6.20 & -16.75 & 0.49 & $+6,55$ & 14,8 \\
Section 2. 10 & 0.25 & 9.70 & -16.30 & 0.87 & $+6,64$ & 13,0 \\
JJP1/A 1 & 0.30 & 7.55 & & 0.63 & & 13,9 \\
Section 2. 20 & 0.35 & 8.20 & -17.25 & 0.62 & $+7,08$ & 15,4 \\
JJP1/A 2 & 0.40 & 10.90 & & 0.95 & & 13,4 \\
Section 2. 30 & 0.45 & 1.40 & -17.62 & 0.13 & $+7,31$ & 12,5 \\
Section 2. 41 & 0.56 & 4.90 & -17.76 & 0.47 & $+7,26$ & 12,2 \\
Section 2. 50 & 0.65 & 1.50 & -20.37 & 0.16 & $+6,27$ & 10,7 \\
Section 2. 60 & 0.68 & 5.40 & -18.09 & 0.52 & $+7,76$ & 12,1 \\
JJP1/A 3 & 0.70 & 8.52 & & 0.72 & & 13,7 \\
Section 2. 70 & 0.76 & 5.20 & & 0.46 & & 13,1 \\
Section 2. 80 & 0.85 & 8.00 & -18.12 & 0.63 & $+7,83$ & 14,8 \\
Section 2.90 & 0.95 & 4.60 & -18.38 & 0.38 & $+7,40$ & 14,4 \\
Section 2.100 & 1.05 & 3.60 & -18.86 & 0.33 & $+8,32$ & 12,6 \\
Section 2.110 & 1.15 & 5.90 & -17.57 & 0.43 & $+9,14$ & 16,2 \\
Section 2.121 & 1.25 & 6.20 & -18.57 & 0.52 & $+8,15$ & 13,9 \\
JJP1/A 4 & 1.29 & 8.59 & & 0.71 & & 14,1 \\
JJP1/A 5 & 1.36 & 5.37 & -19.25 & 0.48 & $+9,12$ & 13,1 \\
Section 2.130 & 1.42 & 6.00 & & 0.52 & & 13,4 \\
Section 2.139 & 1.54 & 1.60 & -19.32 & 0.16 & $+8,35$ & 11,4 \\
JJP1/A 6 & 1.58 & 7.35 & & 0.69 & & 12,5 \\
Section 3.1 & 1.67 & 7.90 & -18.00 & 0.66 & $+6,07$ & 14,1 \\
\hline & & & & & &
\end{tabular}


Table 2 (continued)

\begin{tabular}{|c|c|c|c|c|c|c|}
\hline \multicolumn{7}{|l|}{ Core 11} \\
\hline Sample & $\begin{array}{l}\text { Depth } \\
\text { (m) }\end{array}$ & $\begin{array}{l}\text { TOC } \\
(\%)\end{array}$ & $\delta^{13} \mathrm{C}$ & $\begin{array}{l}\mathrm{TN} \\
(\%)\end{array}$ & $\delta^{15} \mathrm{~N}$ & $\mathrm{C} / \mathrm{N}$ \\
\hline Section 3.10 & 1.76 & 7.70 & -21.40 & 0.53 & $+8,00$ & 16,9 \\
\hline Section 3.20 & 1.86 & 6.70 & -18.60 & 0.53 & $+7,32$ & 14,7 \\
\hline Section 3.30 & 1.96 & 4.80 & -19.67 & 0.34 & $+8,08$ & 16,3 \\
\hline Section 3.40 & 2.06 & 7.00 & -18.93 & 0.69 & $+9,15$ & 11,8 \\
\hline JJP1/A 7 & 2.09 & 5.21 & & 0.46 & & 13,3 \\
\hline JJP1/A 8 & 2.10 & 4.86 & & 0.42 & & 13,4 \\
\hline JJP1/A 9 & 2.11 & 6.93 & & 0.60 & & 13,4 \\
\hline Section 3.50 & 2.16 & 6.30 & -21.30 & 0.48 & $+10,35$ & 15,2 \\
\hline JJP1/A10 & 2.20 & 7.80 & & 0.72 & & 12,6 \\
\hline Section 3.60 & 2.26 & 6.50 & -18.49 & 0.60 & $+8,92$ & 12,6 \\
\hline JJP1/A11 & 2.31 & 6.29 & & 0.59 & & 12,5 \\
\hline Section 3.70 & 2.36 & 6.90 & -17.59 & 0.70 & $+9,75$ & 11,5 \\
\hline JJP1/A12 & 2.41 & 5.82 & & 0.54 & & 12,6 \\
\hline JJP1/B 1 & 2.46 & 5.78 & -18.40 & 0.51 & $+9,84$ & 13,1 \\
\hline JJP1/B 2 & 2.51 & 5.34 & -18.90 & 0.51 & $+8,46$ & 12,3 \\
\hline Section 3.80 & 2.66 & 9.20 & -19.10 & 0.73 & $+9,97$ & 14,8 \\
\hline Section 3.90 & 2.76 & 5.00 & -18.70 & 0.61 & $+9,92$ & 9,5 \\
\hline Section 3.100 & 2.81 & 4.70 & & 0.52 & & 10,6 \\
\hline Section 3.110 & 2.86 & 6.10 & -18.45 & 0.63 & $+9,18$ & 11,3 \\
\hline Section 3.120 & 2.96 & 8.50 & -18.30 & 0.67 & $+8,73$ & 14,7 \\
\hline Section 3.130 & 3.06 & 6.90 & -18.06 & 0.64 & $+10,44$ & 12,6 \\
\hline Section 3.140 & 3.11 & 8.00 & & 0.64 & & 14,6 \\
\hline Section 3.149 & 3.15 & 7.30 & -17.60 & 0.79 & $+6,63$ & 10,8 \\
\hline Section 4.1 & 3.17 & 6.70 & -18.80 & 0.90 & $+8,73$ & 8,7 \\
\hline Section 4.10 & 3.26 & 8.60 & & 0.69 & & 14,5 \\
\hline Section 4.20 & 3.36 & 4.90 & & 0.58 & & 9,8 \\
\hline Section 4.30 & 3.41 & 7.80 & & 0.65 & & 14,0 \\
\hline Section 4.40 & 3.61 & 6.00 & & 0.62 & & 11,2 \\
\hline Section 4.50 & 3.66 & 6.80 & & 0.62 & & 12,7 \\
\hline Section 4.60 & 3.75 & 5.70 & & 0.59 & & 11,2 \\
\hline Section 4.70 & 3.86 & 6.00 & & 0.57 & & 12,4 \\
\hline Section 4.80 & 3.96 & 5.50 & & 0.57 & & 11,2 \\
\hline Section 4.90 & 4.06 & 5.10 & -19.23 & 0.53 & $+8,52$ & 11,3 \\
\hline Section 4.100 & 4.16 & 5.30 & & 0.50 & & 12,4 \\
\hline Section 4.110 & 4.26 & 5.00 & -21.53 & 0.47 & $+8,02$ & 12,5 \\
\hline Section 4.120 & 4.36 & 6.50 & & 0.64 & & 11,8 \\
\hline Section 4.130 & 4.46 & 8.30 & & 0.73 & & 13,2 \\
\hline Section 4.140 & 4.56 & 6.40 & -21.08 & 0.59 & $+8,21$ & 12,7 \\
\hline Section 5.1 & 4.67 & 5.60 & & 0.51 & & 12,7 \\
\hline Section 5.10 & 4.76 & 5.10 & -22.13 & 0.43 & $+6,70$ & 14,0 \\
\hline Section 5.20 & 4.86 & 4.40 & -21.51 & 0.39 & $+5,90$ & 13,1 \\
\hline Section 5.30 & 4.96 & 5.10 & & 0.45 & & 13,3 \\
\hline Section 5.40 & 5.06 & 4.10 & -21.67 & 0.47 & $+5,33$ & 10,3 \\
\hline Section 5.50 & 5.16 & 5.00 & -20.77 & 0.48 & $+4,15$ & 12,2 \\
\hline Section 5.60 & 5.26 & 4.70 & & 0.42 & & 13,1 \\
\hline Section 5.70 & 5.36 & 4.60 & -20.67 & 0.46 & $+4,15$ & 11,8 \\
\hline Section 5.80 & 5.46 & 4.50 & & 0.44 & & 11,9 \\
\hline Section 6.1 & 5.51 & 2.50 & & 0.36 & & 8,1 \\
\hline Section 6.10 & 5.66 & 3.90 & & 0.42 & & 10,7 \\
\hline Section 6.20 & 5.71 & 3.90 & -20.40 & 0.42 & $+4,77$ & 10,7 \\
\hline Section 6.30 & 5.81 & 4.40 & & 0.45 & & 11,4 \\
\hline Section 6.40 & 5.91 & 4.90 & -20.53 & 0.53 & $+2,91$ & 10,9 \\
\hline Section 6.50 & 5.98 & 4.10 & & 0.46 & & 10,4 \\
\hline Section 6.60 & 6.11 & 4.70 & -21.60 & 0.45 & $+1,38$ & 12,3 \\
\hline Section 6.70 & 6.16 & 5.20 & & 0.47 & & 12,9 \\
\hline
\end{tabular}

carbonates) have been ascribed to internal or external causes. Internal causes are high algal productivity and selective ${ }^{12} \mathrm{C}$ uptake linked to persistent eutrophic conditions (Hollander and McKenzie, 1991; Schelske and Hodell, 1995; Gu and Schelske, 1996; Brenner et al., 1999; Meyers, 2003), elimination of light carbon by methanogenesis (Talbot, 1990; Talbot and Kelts, 1990) or high lake water pH and alkalinity (Bade et al., 2004) in lakes with high reservoir effect (Wu et al., 2010). External sources of heavy carbon have been attributed to older carbonate recycling or thermal (and magmatic) $\mathrm{CO}_{2}$ inputs (Valero-Garcés et al., 1999a; Wu et al., 2010).

$\delta^{15} \mathrm{~N}_{\mathrm{AIR}}$ of plankton and aquatic plants in Lake Chungará ( +4 to $+12 \%$ ) are in the range of reported values (Meyers, 2003), reflecting the assimilation of nitrate as $\mathrm{NO}_{3}^{-}$, about $+8 \%$ onriched with respect to atmospheric $\mathrm{N}_{2}$. The $\mathrm{C} / \mathrm{N}$ ratio of plankton and aquatic plants is similar (around 9), being close to that of the recent sediments in the lake bottom (around 11) and far from local land plants (50 on average) (Table 2). These data provide evidence that the main source of organic matter in recent sediments is phytoplankton with minor contributions of aquatic macrophytes (Fritz et al., 2006).

Older sediments show variable isotopic compositions depending on the depositional environment. Higher $\delta^{13} \mathrm{C}$ values on the shallow platform (core 15) than in deeper offshore sediments (core 11) may be ascribed to a greater contribution of aquatic plants (macrophytes) and cyanobacterial colonies from littoral environments. The sediments of core 15 show similar $\delta^{13} \mathrm{C}_{\mathrm{VPDB}}$ values and slightly higher $\mathrm{C} / \mathrm{N}$ values than the recent sediments and are about 3\% lighter than plankton, reflecting a macrophytic contribution. Organic matter in offshore sediments (core 11) is mainly derived from phytoplankton. Its low $\delta^{13} C_{\text {VPDB }}$ values cannot be attributed to mixing with land plants (enriched in ${ }^{12} \mathrm{C}$ ), as is demonstrated by their $\mathrm{C} / \mathrm{N}$ ratios (Table 2). It seems more reasonable to suggest that these $\delta^{13} \mathrm{C}_{\mathrm{VPDB}}$ values $(-17 \%$ in the more recent to $-22 \%$ in the oldest sediments) together with $\mathrm{C} / \mathrm{N}$ ratios between 8 and 17 (12.7 in average) reflect the algal contribution to the total organic matter in the lake sediments (Meyers, 1997; Meyers and Teranes, 2001).

TOC- $\delta{ }^{13} \mathrm{CVPDB}_{\text {VPd }}$ (and to a lesser extent $\delta^{13} \mathrm{C}$ in carbonates) of Lake Chungará displays increasing values throughout the sedimentary sequence (Fig. 7). A similar trend from lower to higher $\delta^{13} C_{\mathrm{VPDB}}$ has been reported in other lake systems and ascribed to increases in aquatic productivity (Hollander and McKenzie, 1991; Meyers, 2003). Isotopic fractionation produced in the early stages of microbial degradation due to a partial oxidation of organic matter (Lehmann et al., 2002) should be ruled out in the absence of significant changes in the $\mathrm{C} / \mathrm{N}$ ratio with depth (Table 2). Therefore, other heavy carbon inputs are necessary to account for all the $\delta^{13} \mathrm{C}_{\mathrm{VPDB}}$ values in Lake Chungará.

The highest DIC- $\delta{ }^{13} \mathrm{C}_{\mathrm{VPDB}}$ values in natural lacustrine environments reported in the literature are around $+26 \%$ and correspond to pore-water affected by methanogenesis in Lake Bosumtwi (Ghana; Talbot and Kelts, 1986) and Lake Apopka (Florida, USA; Gu et al., 2004) (Fig. 8). ${ }^{13} \mathrm{C}$ enrichment is smaller in the water column (Lake Apopka DIC- $\delta{ }^{13} \mathrm{C}_{\mathrm{VPDB}}$ from +5 to $+13 \%$ ) and has been attributed to advection of heavy carbon through the water-sediment interface and to the DIC speciation at high $\mathrm{pH}$ values $\left(>8.3\right.$ ) where $\mathrm{HCO}_{3}^{-}$is the dominant ionic form (Deuser and Degens, 1967; Hassan et al., 1997; Keeley and Sandquist, 2006). The high $\delta^{13} C_{\text {VPDB }}$ values in Lake Chungará (in DIC, endogenic carbonate and TOC; Tables 1,2 and 3) are similar to those reported in Lake Apopka. DIC- $\delta{ }^{13} C_{\text {VPDB }}$ pore-water values, calculated from endogenic carbonate sediments of Lake Chungará, are in the highest range (around $+23 \%$ ). Moreover, the DIC system is currently dominated by $\mathrm{HCO}_{3}^{-}$(Mühlhauser et al., 1995; Risacher et al., 1999; Herrera et al., 2006). Recent DIC- $\delta{ }^{13} C_{\mathrm{VPDB}}$ values in the water column $\left(+3\right.$ to $+6 \%$ ) and $\delta^{13} \mathrm{C}_{\mathrm{VPDB}}$ values in endogenic carbonate crystals ( +3 to $+6 \%$ in cores 11 and 14 , and $+12 \%$ o in core $93 \mathrm{~L}$, this last core located in a littoral setting) are similar to those reported in Lake Apopka (Gu et al., 2004; Fig. 8).

$\delta^{15} \mathrm{~N}_{\text {AIR }}$ values show a contrasting behaviour with respect to $\delta^{13} C_{\text {VPDB }}$. The values are more positive in offshore (core 11) than in littoral sediments (core 15; Fig. 5A) of Lake Chungará. Lower marginal $\delta{ }^{15} \mathrm{~N}_{\text {AIR }}$ values probably reflect cyanobacterial activity and land inputs. The gradual increase in $\delta{ }^{15} \mathrm{~N}_{\mathrm{AIR}}$ (from +1 to $+10 \%$ ) and TN between 12.3 and 7.2 cal kyr BP (Fig. 7) may be linked to an increase in algal productivity, matching approximately the behaviour of carbon (Meyers and Teranes, 2001).

From 12.3 (the beginning of the sequence) to $10.2 \mathrm{cal} \mathrm{kyr} \mathrm{BP}$, in subunit $1 \mathrm{a}$, the increase in TOC, TN, TOC- $\delta{ }^{13} \mathrm{C}_{\mathrm{VPDB}}$ and $\mathrm{TN}-\delta^{15} \mathrm{~N}_{\mathrm{AIR}}$ suggests a rise in productivity with a maximum around 11 cal yr BP (Fig. 7). This increase in productivity could be related to external inputs associated with runoff during a lake level rise (Sáez et al., 2007). 


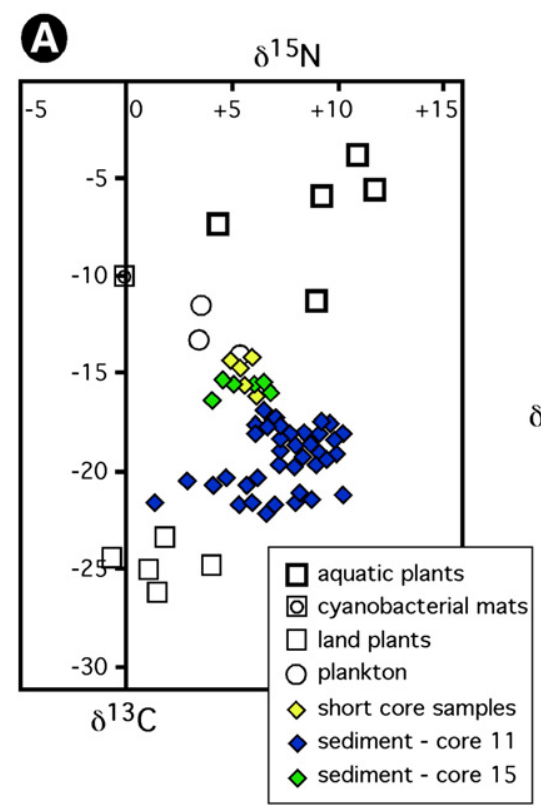

B

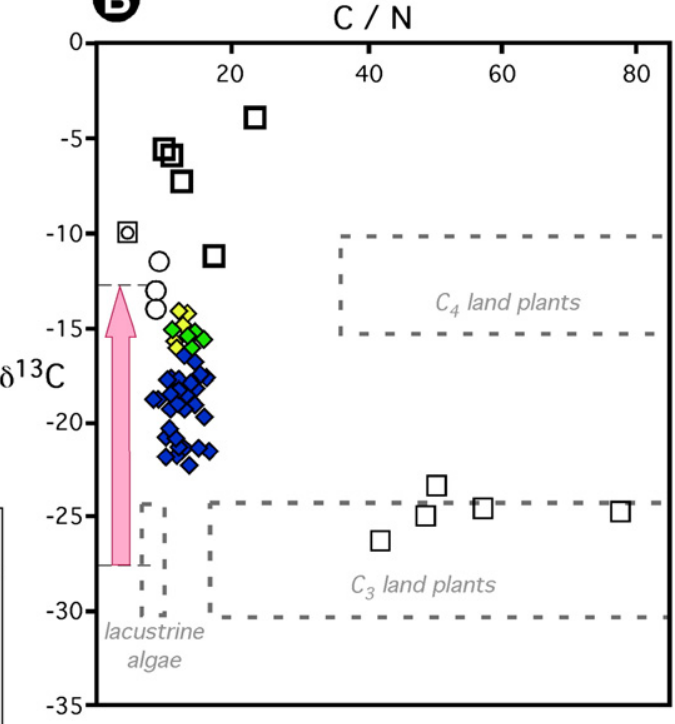

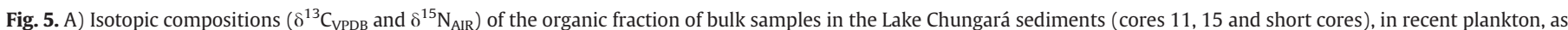

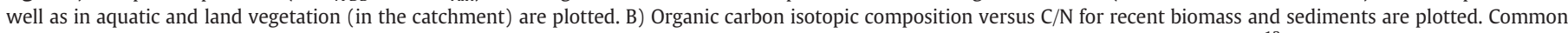
values for lacustrine phytoplankton and $C_{3}$ and $C_{4}$ land plants are indicated (after Meyers, 1994). Recent plankton from Lake Chungará shows ${ }^{13} \mathrm{C}$ enrichment around $+15 \%$.

Furthermore, this change could have increased the surface of the photic zone of the lake, reflecting higher contributions of cyanobacterial colonies and other algae (Botryococcus) as biological producers. This matches the values reported for living macrophytes of Lake Chungará (Table 2, Fig. 5) and other altiplanic lakes (Lake Titicaca, in the PeruBolivia border; Fritz et al., 2006). The low $\mathrm{TN}-\delta^{15} \mathrm{~N}_{\text {AIR }}$ values, which are close to $0 \%$ in the early and shallower stages of the recorded sedimentary sequence, suggest a biomass dominated by cyanobacteria (Meyers, 2003).

\subsection{Origin of carbonates}

The carbon isotopic composition of carbonates from the Lake Chungará sediments increases from offshore towards the littoral sediments (Fig. 6A). Charophyte-rich sediments in the eastern margin (core 93L, about $+9 \%$ in average) and calcite-rich laminae in recent sediments ( +9 to $+5 \%$; Valero-Garcés et al., 2003 ) record the heaviest values. Isotopic analyses $\left(\delta^{13} \mathrm{C}_{\mathrm{VPDB}}\right.$ and $\left.\delta^{18} \mathrm{O}_{\mathrm{VPDB}}\right)$ were performed along the same carbonate keybed, identified in cores 11 and 14 (both located in offshore settings), displaying similar values around $+4 \%$ o for $\delta{ }^{13} \mathrm{C}_{\mathrm{VPDB}}$ and from 0 to $-2 \%$ for $\delta^{18} \mathrm{O}_{\mathrm{VPDB}}$ (Fig. 4). Slightly higher $\delta^{13} \mathrm{C}_{\mathrm{VPDB}}$ in core 14 than in core 11 can also be ascribed to the local influence of higher productivity in a more littoral setting. Evaporation in littoral areas and the local effect of photosynthesis associated with macrophytes would account for the increase in $\delta^{13} C_{\mathrm{VPDB}}$. Nevertheless, values exceeding $+7 \%$ suggest other sources of heavy carbon. In Lake Chungará, where there is evidence of anoxia and gas accumulation in the bottom sediments, synsedimentary methanogenesis has to be considered as a possible origin for heavy isotopic carbonate compositions. Evidence of trapped gas (methane?) has been interpreted in the seismic profiles of the eastern platform, where core 15 is located (Fig. 4 in Sáez et al., 2007). Two carbonate samples from core 15 , on the eastern platform of the lake, show the highest values of $\delta^{13} \mathrm{C}_{\mathrm{VPDB}}(+13$ and $+23 \%$ ) (Table 3, Fig. $6 \mathrm{~A})$. Both samples are the only ones that show an incipient early cementation that replaces earlier minerals (probably $\mathrm{CaCO}_{3}$ precursors such as ikaite) (Fig. 3J). Calcite spherulites with similar methanogenic signatures have been described in Lake Bosumtwi (Talbot and Kelts, 1986). Methanogenic fermentation in the sediments may have caused methane releases to the water column, thus increasing the pore-water DIC, rich in ${ }^{13} \mathrm{C}$, resulting in Ca-carbonate local replacements. These higher $\delta^{13} \mathrm{CVPDB}_{\mathrm{VPD}}$ values in early diagenetic cements are evidence of bacterial methanogenesis (Turner and Fritz, 1983). The general trend towards higher $\delta^{13} C_{\text {VPDB }}$ values in carbonates along the whole sequence (Fig. 7) would be a consequence of changes in biological (increase in organic productivity) and chemical (increase in $\mathrm{pH}$ and alkalinity) parameters causing higher DIC- $\delta{ }^{13} \mathrm{C}_{\mathrm{VPDB}}$. The influence of geothermal and volcanic $\mathrm{CO}_{2}$ and degassing during groundwater discharge has been proposed in the shallow lakes of the Andean Altiplano as a ${ }^{13} \mathrm{C}$ enrichment mechanism (Schwalb et al., 1999; Valero-Garcés et al., 1999a, 2000; Gibert et al., 2008). Nevertheless, these processes cannot be applied here. Lake Chungará is neither a saline nor a shallow lake, and it provides no evidence of thermal inputs. Moreover, it is a young lake without a long history of interactions with the surrounding volcanic environment.

The oxygen isotopic composition of carbonates depends on the isotopic composition and on the temperature of the host water. In highaltitude Andean lakes, the isotopic water composition is the main factor that is dependent on the input waters (rainfall, groundwaters and runoff) and on evaporative enrichment (Aravena et al., 1999). The Lake Chungará waters are heavier than inputs (springs, rivers, and rainfall) due to the strong evaporation in the Altiplano arid environment (Table 1; Fig. 7 in Herrera et al., 2006). The $\delta^{18} \mathrm{O}_{\mathrm{VPDB}}$ values of carbonates, ranging roughly from +4 to $-4 \%$ (Table 3 , Fig. $6 \mathrm{~A}$ ) show a clear relationship with the depositional environment: samples from littoral zones of the lake are isotopically lighter than those from offshore areas. Although the variability of the bulk sediment samples is very large, the calcite-rich levels from the short-core 93S show a range similar ( 0 to $-4 \%$ ) to that of the separated charophyte stems $(-1$ to $-5 \%$ o). Lower isotopic compositions of carbonates suggest inputs of lighter waters and the effect of warmer temperatures in coastal settings. The most likely source is freshwater input and seepage of groundwater in the NE basin.

\subsection{Controls on carbonate precipitation}

Changes in the carbonate content and mineralogy in the sediments of Lake Chungará record variations in the water chemistry and also in 


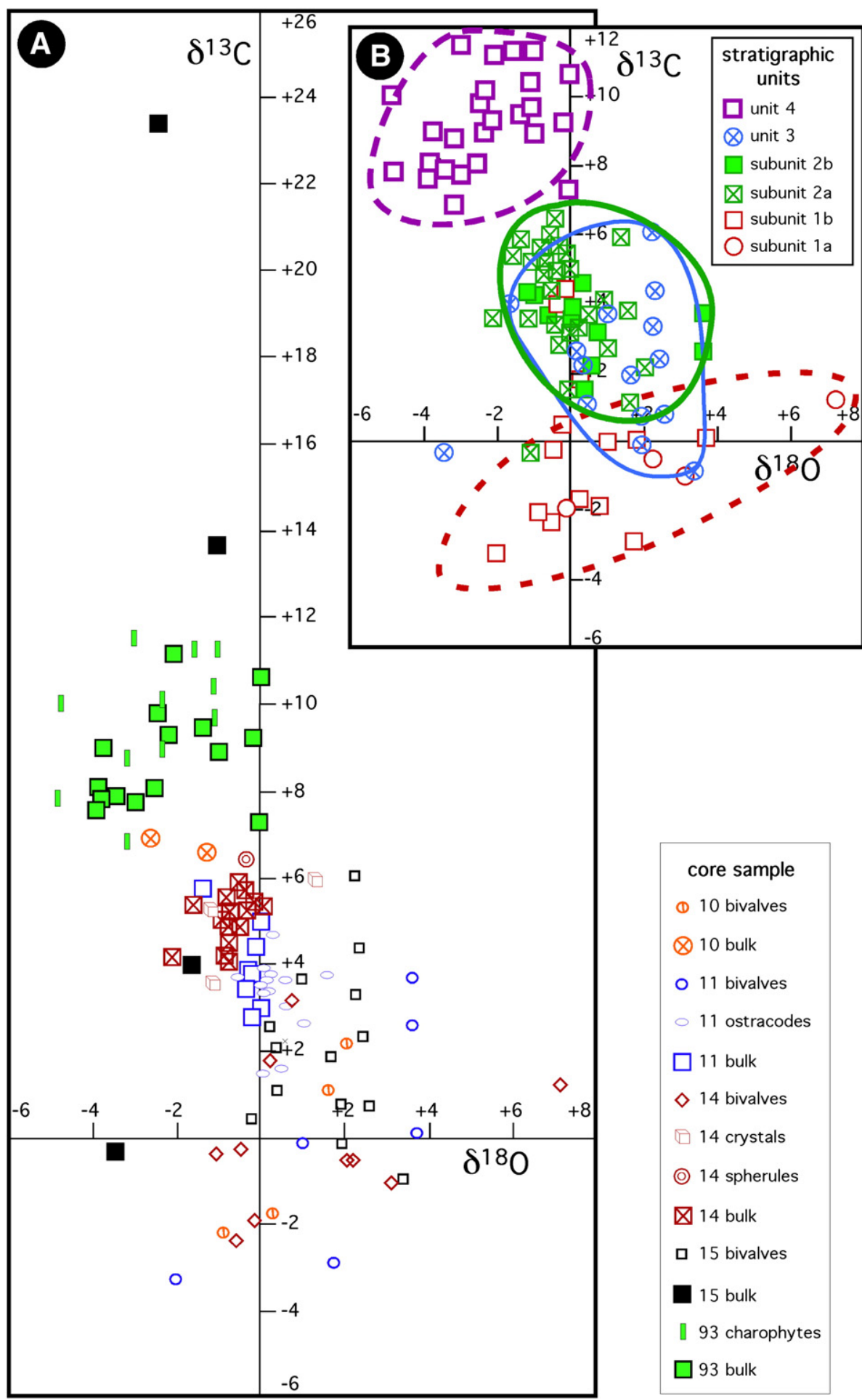

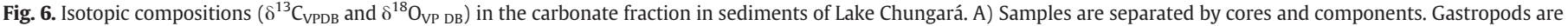
not plotted. B) Samples are separated by stratigraphic units.

the type and productivity of biomass in space and time. Thus, a low calcium concentration in waters during the early stages of lake evolution would be responsible for the negligible amount of calcium carbonate precipitation (i.e. in Unit 1, 12.3 to 8.3 cal kyr BP, Figs. 2 and 9). A possible explanation for relatively Ca-poor waters during the early lake stage could be the short leaching time of volcanic rocks in the catchment after the collapse that had dammed the River Lauca, creating the lake. Thereafter, the availability of calcium in waters could have increased with time, giving rise to conditions that favoured a higher (although never dominant) calcium carbonate precipitation, mainly in subunit 2a, 8.3 to 3.55 cal kyr BP. The rise in calcium in lake waters is also consistent with the marked increase in tephra intercalations starting from the beginning of Unit 2 (Sáez et al., 2007). In fact, the onset of a significant precipitation of carbonates can be related to extreme photosynthetic activity associated with massive diatom blooms during a short dry period from 10.0 to 9.6 cal yr BP 
Table 3

Isotopic compositions $\left(\delta^{13} \mathrm{C}_{\mathrm{VPDB}}, \delta^{18} \mathrm{O}_{\mathrm{VPDB}}\right.$ ) of the carbonate fraction in the Lake Chungará sediments. Results are grouped by cores $(10,11,14,15$ and 93). The kind of analysed samples (bulk samples, microsamples, isolated components) is indicated in the 'compo' column. Gastropods are aragonitic, bivalves and ostracods are calcitic, carbonate crystals are calcite (only one aragonite level has been analysed) and spheroids are aragonitic.

\begin{tabular}{|c|c|c|c|c|c|}
\hline Sample & Depth-cm & ${ }^{14} \mathrm{C}$ age ${ }^{\mathrm{a}}$ & $\delta 13 C_{\mathrm{PDB}}$ & $\delta 180_{\mathrm{PDB}}$ & Compo $^{\mathrm{b}}$ \\
\hline \multicolumn{6}{|l|}{ Core 10} \\
\hline $10 a 1-24$ & 24 & & 1.52 & 0.39 & Bivalve - LMC \\
\hline $10 a 1-44$ & 44 & & 2.21 & 0.57 & Bivalve - LMC \\
\hline $10 a 4-13$ & 370 & & 1.09 & 1.64 & Bivalve - LMC \\
\hline 10a4-96 & 453 & & 2.19 & 2.06 & Bivalve (?) \\
\hline $10 a 4-112$ & 469 & & -1.96 & 0.77 & Bivalve - LMC \\
\hline $10 a 4-114$ & 471 & & -1.76 & 0.28 & Bivalve - LMC \\
\hline $10 a 4-118$ & 475 & & -2.14 & -0.84 & Bivalve - LMC \\
\hline \multicolumn{6}{|l|}{ Core 11} \\
\hline $11 \mathrm{a} 2-1$ & 16 & & 3.71 & -0.54 & Ostracode - LMC \\
\hline $11 a 2-3$ & 18 & & 3.70 & 3.65 & Bivalve (?) \\
\hline $11 \mathrm{a} 2-10$ & 25 & & 4.29 & -1.14 & Ostracode - LMC \\
\hline $11 \mathrm{a} 2-20$ & 35 & & 4.23 & -0.82 & Ostracode - LMC \\
\hline $11 \mathrm{a} 2-30$ & 45 & & 3.90 & 0.05 & Ostracode - LMC \\
\hline $11 \mathrm{a} 2-40$ & 55 & 2075 & 2.59 & 3.64 & Bivalve (?) \\
\hline $11 \mathrm{a} 2-41$ & 56 & & 3.62 & 0.15 & Ostracode - LMC \\
\hline $11 \mathrm{a} 2-50$ & 65 & & 3.52 & 0.04 & Ostracode - LMC \\
\hline $11 \mathrm{a} 2-80$ & 95 & 3470 & 4.64 & 0.35 & Ostracode - LMC \\
\hline $11 \mathrm{a} 2-90$ & 105 & & 3.61 & 0.60 & Ostracode - LMC \\
\hline $11 \mathrm{a} 2-100$ & 115 & & 4.07 & 0.93 & Ostracode - LMC \\
\hline $11 a 2-110$ & 125 & & 3.75 & 0.26 & Ostracode - LMC \\
\hline $11 \mathrm{a} 2-121$ & 136 & & 3.35 & 0.17 & Ostracode - LMC \\
\hline $11 \mathrm{a} 2-130$ & 145 & & 3.74 & 0.11 & Ostracode - LMC \\
\hline $11 a 2-139$ & 154 & & 3.72 & 1.62 & Ostracode - LMC \\
\hline $11 a 3-5$ & 171 & 6390 & 3.86 & -0.21 & Bulk $^{\mathrm{c}}$ \\
\hline $11 \mathrm{a} 3-10$ & 176 & & 3.42 & 0.05 & Ostracode - LMC \\
\hline $11 a 3-10$ & 176 & & 4.98 & 0.00 & Bulk \\
\hline $11 a 3-20$ & 186 & & 2.62 & 1.04 & Ostracode - LMC \\
\hline $11 \mathrm{a3}-20$ & 186 & & 2.76 & -0.21 & Bulk \\
\hline 11a3-30 & 196 & & 1.54 & 0.53 & Ostracode - LMC \\
\hline $11 a 3-40$ & 206 & & 1.48 & 0.07 & Ostracode - LMC \\
\hline $11 a 3-50$ & 216 & & 3.03 & 0.69 & Ostracode - LMC \\
\hline $11 \mathrm{a} 3-50$ & 216 & & 3.42 & -0.34 & Bulk \\
\hline $11 \mathrm{a} 3-55$ & 221 & & 2.97 & 0.00 & Bulk \\
\hline 11a3-90 & 256 & 8150 & 5.76 & -1.35 & Bulk \\
\hline 11a3-93 & 259 & & -0.06 & 1.03 & Bivalve - LMC \\
\hline 11a3-95 & 261 & & 4.41 & -0.09 & Bulk \\
\hline $11 a 3-100$ & 266 & & 3.88 & -0.30 & Bulk - A \\
\hline 11a3-108 & 274 & & -3.27 & -1.99 & Bivalve - LMC \\
\hline $11 a 3-112$ & 278 & & -2.94 & 1.78 & Bivalve - LMC \\
\hline $11 a 3-115$ & 281 & 8800 & 0.08 & 3.77 & Bivalve - LMC \\
\hline $11 a 3-132$ & 298 & & 3.01 & -0.66 & Bulk microsample \\
\hline 11a3-133 & 299 & & 3.01 & -0.83 & Bulk microsample \\
\hline 11a3-139,5 & 305.5 & & 1.89 & -1.31 & Bulk microsample \\
\hline 11a3-140 & 306 & & -0.07 & 1.94 & Bivalve - LMC \\
\hline $11 \mathrm{a} 4-4$ & 320 & & -0.07 & -2.52 & Bulk microsample \\
\hline $11 \mathrm{a} 4-6$ & 322 & & 1.82 & -2.14 & Bulk microsample \\
\hline $11 \mathrm{a} 4-10$ & 326 & 9610 & 3.18 & -1.24 & Bulk microsample \\
\hline $11 \mathrm{a} 4-11,5$ & 327.5 & & 2.32 & -1.41 & Bulk microsample \\
\hline $11 \mathrm{a} 4-14$ & 330 & & 3.47 & -0.98 & Bulk microsample \\
\hline $11 \mathrm{a} 4-17,5$ & 333.5 & & 0.35 & -1.66 & Bulk microsample \\
\hline $11 \mathrm{a} 4-40$ & 356 & & 0.61 & -2.86 & Bulk microsample \\
\hline $11 \mathrm{a} 4-42$ & 358 & & 5.07 & -2.24 & Bulk microsample \\
\hline $11 \mathrm{a} 4-44$ & 360 & & 3.61 & -2.43 & Bulk microsample \\
\hline $11 \mathrm{a} 4-46$ & 362 & & -1.74 & -2.52 & Bulk microsample \\
\hline $11 a 4-51,5$ & 367.5 & 10,370 & 6.79 & -0.88 & Bulk microsample \\
\hline \multicolumn{6}{|l|}{ Core 15} \\
\hline $15 a 1-37$ & 37 & & 3.65 & 1.02 & Gastropod - A \\
\hline $15 a 1-43$ & 43 & & 6.05 & 2.24 & Bivalve - LMC \\
\hline $15 a 1-45$ & 45 & & 4.37 & 2.36 & Gastropod - A \\
\hline $15 a 1-63$ & 63 & & 2.35 & 2.44 & Bivalve - LMC \\
\hline $15 a 2-37$ & 134 & & 3.98 & -1.64 & Bulk \\
\hline $15 a 2 \cdot 48$ & 145 & & 23.38 & -2.44 & Bulk \\
\hline $15 a 2-70$ & 152 & & 2.57 & 0.21 & Bivalve - LMC \\
\hline $15 a 2-72$ & 154 & & 2.11 & 0.38 & Bivalve - LMC \\
\hline 15a3-76 & 244 & & 0.73 & 1.97 & Gastropod - A \\
\hline $15 a 3-130$ & 316 & & 2.06 & 0.37 & Bivalve - LMC \\
\hline $15 a 3-134$ & 320 & & -0.14 & 1.96 & Bivalve - LMC \\
\hline 15a3-139 & 325 & & 0.75 & 2.60 & Bivalve - LMC \\
\hline $15 a 4-3$ & 321 & & 13.63 & -1.04 & Bulk \\
\hline
\end{tabular}

Table 3 (continued)

\begin{tabular}{|c|c|c|c|c|c|}
\hline Sample & Depth-cm & ${ }^{14} \mathrm{Cage}^{\mathrm{a}}$ & $\delta 13 C_{\text {PDB }}$ & $\delta 180_{\mathrm{PDB}}$ & Compo $^{\mathrm{b}}$ \\
\hline $15 a 4-68$ & 386 & & 1.89 & 1.70 & Bivalve (fragment) \\
\hline $15 a 4-72$ & 390 & & 1.06 & 0.41 & Bivalve - LMC \\
\hline $15 a 4-80$ & 398 & & 3.31 & 2.29 & \\
\hline $15 a 4-95$ & 413 & & -0.94 & 3.39 & \\
\hline 15a4-99 & 417 & & -0.34 & -3.45 & Bulk \\
\hline $15 a 4-137$ & 455 & & 0.44 & -0.20 & Bivalve - LMC \\
\hline Sample & depth-cm & $\delta 13 C_{\mathrm{PDB}}$ & \multicolumn{2}{|c|}{$\delta 180_{\mathrm{PDB}}$} & Compo \\
\hline \multicolumn{6}{|l|}{ Core 14} \\
\hline 14a1-15 & 15 & 3.17 & \multicolumn{2}{|c|}{0.75} & Bivalve - LMC \\
\hline $14 \mathrm{a} 2-140$ & 415 & 3.54 & \multicolumn{2}{|c|}{-2.14} & Bulk \\
\hline $14 a 3-6$ & 281 & 5.90 & \multicolumn{2}{|c|}{1.35} & Carbonate cryst. LMC \\
\hline $14 a 3-8$ & 283 & 5.88 & \multicolumn{2}{|c|}{-0.50} & Bulk \\
\hline $14 a 3-9$ & 284 & 5.70 & \multicolumn{2}{|c|}{-0.41} & Bulk \\
\hline $14 a 3-12$ & 287 & 5.37 & \multicolumn{2}{|c|}{-1.54} & Bulk \\
\hline $14 a 3-8$ & 293 & 5.19 & \multicolumn{2}{|c|}{-1.00} & Carbonate cryst. LMC \\
\hline $14 a 3-18$ & 293 & 6.44 & \multicolumn{2}{|c|}{-0.41} & Spherulae - A \\
\hline $14 a 3-20$ & 295 & 4.18 & \multicolumn{2}{|c|}{-0.76} & Bulk \\
\hline $14 a 3-22$ & 297 & 3.50 & \multicolumn{2}{|c|}{-1.17} & Carbonate cryst. LMC \\
\hline $14 a 3-24$ & 299 & 5.51 & \multicolumn{2}{|c|}{-0.80} & Bulk \\
\hline $14 a 3-26$ & 301 & 5.25 & \multicolumn{2}{|c|}{-0.72} & Bulk \\
\hline $14 a 3-28$ & 303 & 5.39 & \multicolumn{2}{|c|}{-0.12} & Bulk \\
\hline $14 a 3-30$ & 305 & 5.32 & \multicolumn{2}{|c|}{-0.03} & Bulk \\
\hline $14 a 3-32$ & 307 & 5.25 & \multicolumn{2}{|c|}{-0.30} & Bulk \\
\hline $14 a 3-34$ & 309 & 5.21 & \multicolumn{2}{|c|}{-0.75} & Bulk \\
\hline $14 a 3-36$ & 311 & 5.13 & & 88 & Bulk \\
\hline $14 a 3-40$ & 315 & 5.09 & & .72 & Bulk \\
\hline $14 a 3-42$ & 317 & 4.84 & & 45 & Bulk \\
\hline $14 a 3-44$ & 319 & 4.70 & & 64 & Bulk \\
\hline $14 a 3-46$ & 321 & 4.52 & & .74 & Bulk \\
\hline $14 a 3-82$ & 357 & 4.07 & & 71 & Bulk \\
\hline 14a3-105 & 380 & -0.36 & & .05 & Bivalve - LMC \\
\hline $14 a 3-127$ & 402 & -0.54 & & 19 & Bivalve - LMC \\
\hline $14 a 3-129$ & 404 & -0.27 & & 47 & Bivalve - LMC \\
\hline 14a3-131 & 406 & -2.38 & & .51 & Bivalve - LMC \\
\hline $14 a 3-145$ & 420 & 1.78 & & 26 & Gastropod - A \\
\hline $14 a 4-25$ & 450 & -1.94 & & .08 & Bivalve - LMC \\
\hline $14 a 4-32$ & 457 & -0.50 & & 27 & Bivalve - LMC \\
\hline $14 a 4-32$ & 457 & 1.22 & & 26 & Bivalve - LMC \\
\hline $14 a 4-35$ & 460 & -1.05 & & 15 & Bivalve - LMC \\
\hline
\end{tabular}

Core $93 \mathrm{~L}$

1993-16

$1993-24$

$1993-30$

1993-35

$1993-49$

$1993-50$

$1993-58$

$1993-82$

1993-120

1993-123

1993-136

1993-139

1993-150

1993-155

1993-165

1993-171

1993-176

1993-180

1993-183

1993-192

1993-285

1993-287

1993-298

1993-301

1993-310

1993-312

16
24
30
35
49
50
58
82
120
123
136
139
150
155
165
171
176
180
183
192
285
287
298
301
310
312

10.13

8.97

9.77

11.48

11.16

8.90

10.61

9.44

9.28

11.27

7.84

8.76

8.07

7.87

8.04

7.72

7.59

6.82

7.82

10.02

7.26

9.67

10.40

11.27

9.22

8.96
$-2.33$

$-3.73$

$-2.43$

$-3.00$

$-2.06$

$-0.99$

$-1.37$

$-2.17$

$-1.56$

$-3.80$

$-3.16$

$-3.84$

$-3.41$

$-2.53$

$-2.98$

$-3.89$

$-3.15$

$-4.80$

$-4.87$

$-0.02$

$-1.06$

$-1.10$

$-1.01$

$-0.17$

$-2.33$
Charophytes ${ }^{\mathrm{e}}$

Bulk

Bulk

Charophytes

Bulk

Bulk

Bulk

Charophytes

Bulk

Charophytes

Bulk

Bulk

Bulk

Bulk

Charophytes

Charophytes

Charophytes

Bulk

Charophytes

Charophytes

Charophytes

Bulk

Charophytes a Calendar years BP.

b Sample tipe (bulk, bioclast, crystal), main mineralogy (A, LMC, HMC). A: aragonite. LMC: low magnesium calcite. HMC: high magnesium calcite.

Bulk samples mostly contain carbonate crystals with diatomitic ooze Nevertheless, some mixing with bioclasts is possible. In core 93L bulk microsamples contain charophyte remains and diatomitic ooze.

d Bulk microsamples contain carbonate crystals mixed with diatomitic ooze.

e Charophyte samples are commonly stems and mixtures of LMC and HMC. 


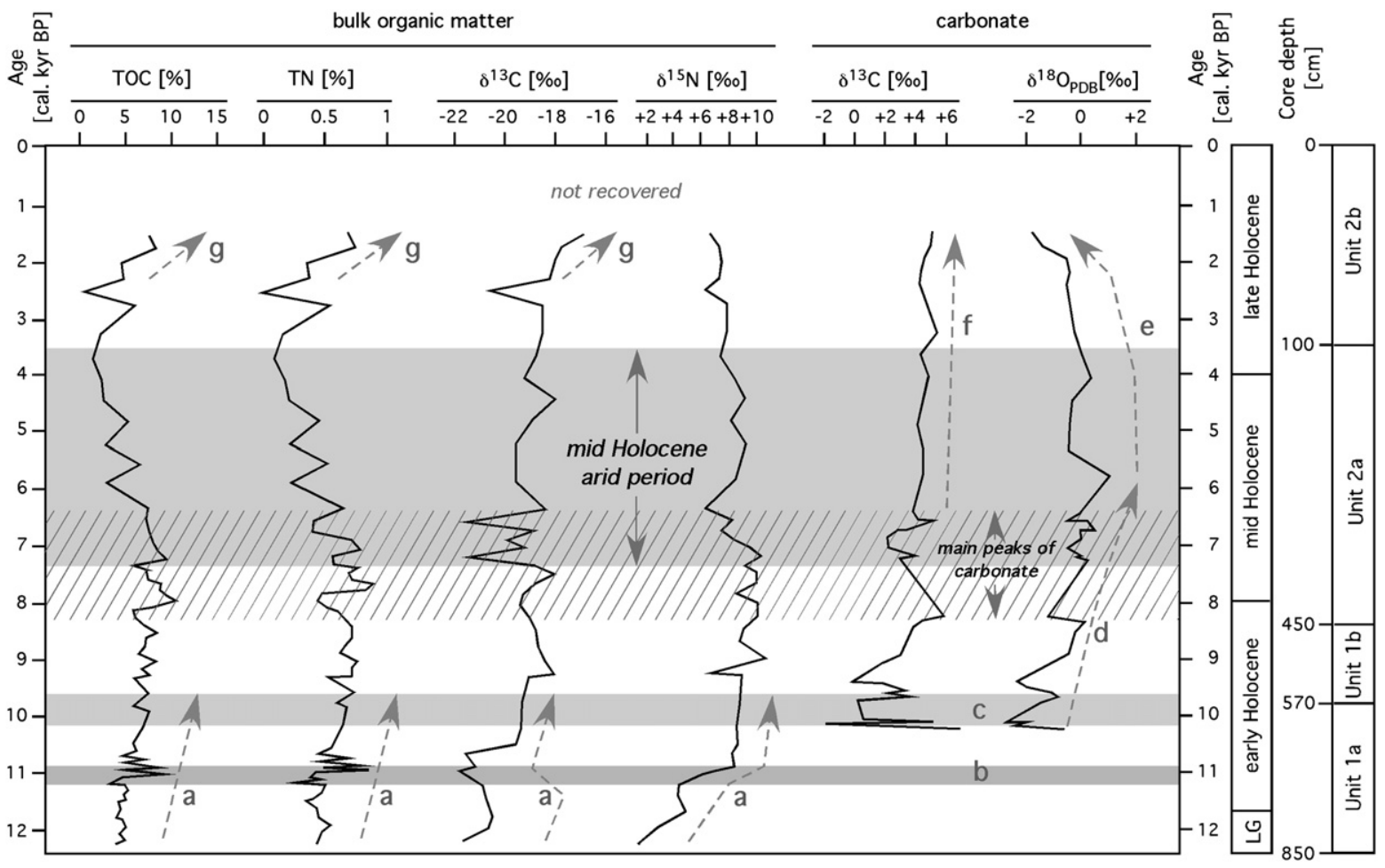

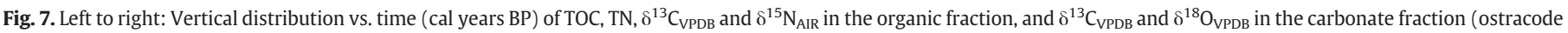

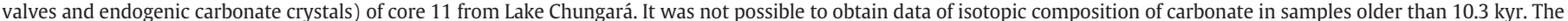

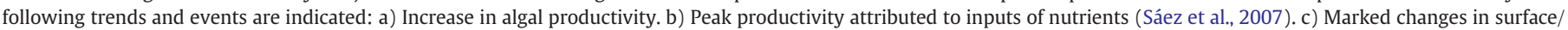

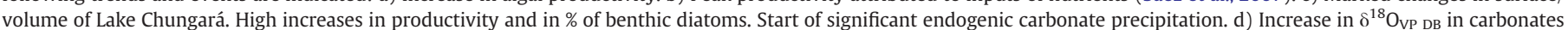

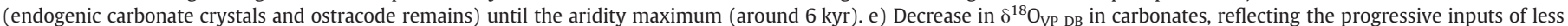
evaporated meteoric waters. f) Stability in DIC, probably reflecting few changes in the type of biomass and organic matter provenance. g) Increase in productivity.

(Bao et al., 2010). The absence of calcium was probably the limiting factor in the early stages of lake evolution (Fig. 7) when phytoplankton productivity was dominant.

Changes in type and distribution of carbonates were attributed to the type and amount of biomass and to hydrologic gradients generated by surface streams in the lake. These gradients and surface streams were controlled by dominant winds, and by surface and underground water inputs to the lake. The deposition of mm-thick carbonate layers covering the whole or a considerable part of the lake must be interpreted as an endogenic bioinduced (due to bacterial and algal activity) and hydrologically controlled precipitation. Experimental studies have shown that differences in calcite (and high-Mg calcite) grain shape and size are generated by growth in a bacterial exopolysaccharide matrix with varying contents of amino acids (Braissant et al., 2003): (a) in the presence of varying concentrations of proteins (lysozyme; Jiménez-López et al., 2003), (b) in gel bacterial cultures (GonzálezMuñoz et al., 2000) or (c) in a gelatinous matrix with varying amounts of $\mathrm{Mg}^{2+}$ (Fernández-Díaz et al., 1996). The changes in morphology and mineralogy observed in the carbonates of Lake Chungará may be the result of variations in the $\mathrm{Mg} / \mathrm{Ca}$ in the water body and the influence of organic matrices. Aragonite precipitation has been attributed to the loss of $\mathrm{CO}_{2}$ in waters with $\mathrm{Mg} / \mathrm{Ca}$ ratios exceeding 3 (Bischoff and Fyfe, 1968; Müller et al., 1972; Barkan et al., 2001). This is consistent with the almost monomineral nature (aragonite or calcite) of single offshore carbonate levels. The most recent offshore sediments of Lake Chungará lack aragonite levels, indicating that the $\mathrm{Mg} / \mathrm{Ca}$ molar ratio in the lake waters was commonly under this value. A single change from calcite (in the deeper part of the lake) to aragonite needle-shaped crystals (on the eastern platform of the lake) was observed along an individual $\mathrm{cm}$-thick carbonate-rich level at a distance of about $4 \mathrm{~km}$. This can be explained by local simultaneous or quasi-simultaneous changes in the water inputs. Both minerals are usually mixed as calcite crystals and aragonite spheroids in marginal areas of the lake (Fig. 3). This is due to the mixing of benthic aragonite spheroids with bloom-related calcite crystals. Similar spheroids in aragonite showing inner radial structure were grown in biofilms and gels (Suess and Fütterer, 1972; Fernández-Díaz et al., 1996) and have also been described for calcite and vaterite (Giralt et al., 2001), suggesting that organic mucilages such as bacterial or cyanobacterial polysaccharides could control the resultant mineralogy and shape (Braissant et al., 2003). Benthic photosynthetic cyanobacteria that are present in the coastal areas of Lake Chungará would provide the exclusive matrix in which aragonite spheroids grew (Défarge et al., 1996).

Algal blooms causing $\mathrm{CO}_{2}$ photosynthetic depletions and $\mathrm{Ca}^{2+}$ inputs coming from marginal aquifers are the limiting factors in the precipitation of the mm-thick Ca-carbonate layers. In fact, Ca-carbonate precipitation in offshore areas reflects the combined effect of several factors: at short time scales the effect of algal blooms, at intermediate time scales the effect of evaporation, and at long time scales, modifications in water chemistry due to changes in watershed rock composition, direct volcaniclastic inputs to the lake, and weathering (Sáez et al., 2007). The enhancement of endogenic carbonate precipitation during wet periods has been related to increases in the aquifer recharge rate, and to Ca inputs into previously Ca-depleted waters (Julià et al., 1998; Shapley et al., 2005; Romero et al., 2006). Moreover, these inputs increased the productivity of macrophytes (Chara, Myriophyllum) and benthic algae in the marginal areas and platforms of the lake, resulting in local $\mathrm{CO}_{2}$ depletions where the photic zone reached the lake bottom. This together with the $\mathrm{Ca}^{2+}$ marginal gradient accounts for the higher amount and the larger size of the Ca-carbonate components in the lake littoral sediments.

The isotopic evolution along time, given the data from cores 11,14 , 15 and 93L (separated by sedimentary units; Fig. 6B) shows changes in range and covariance that can be significant. The variability and 


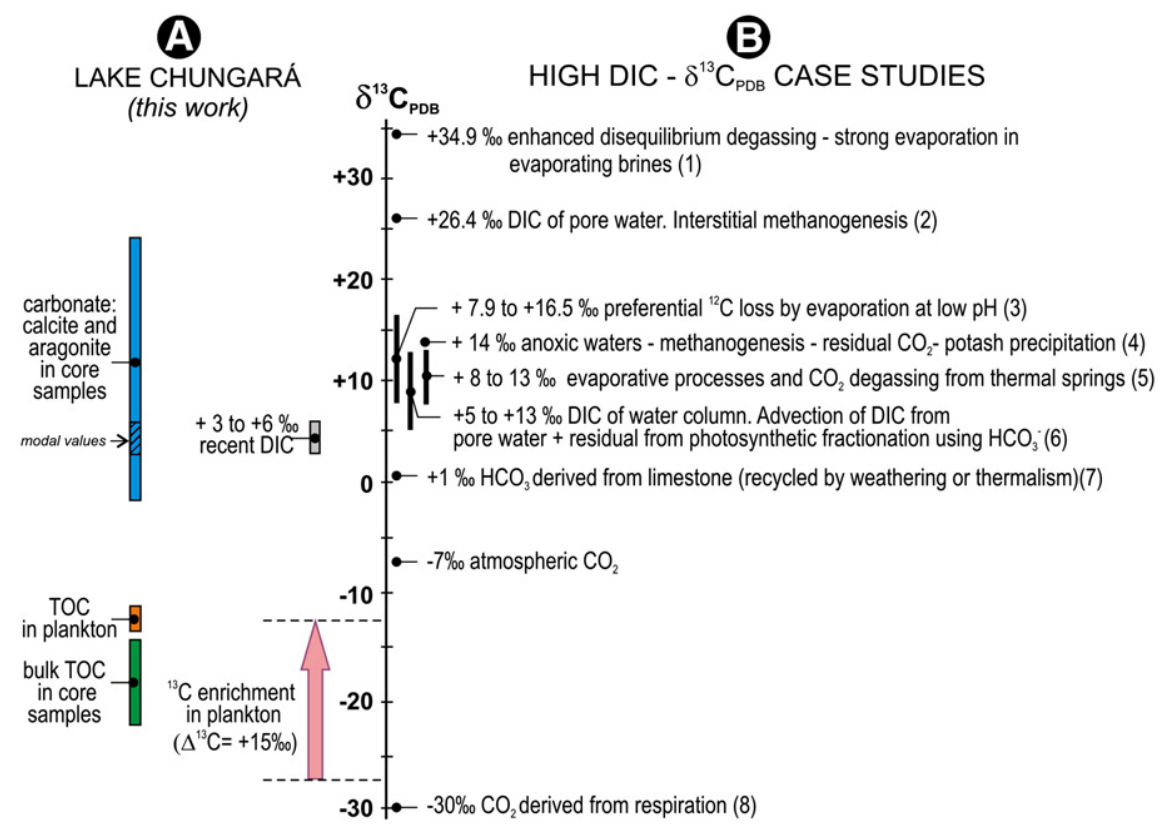

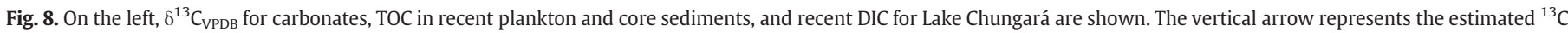

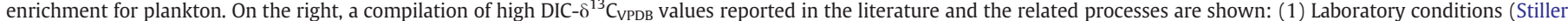

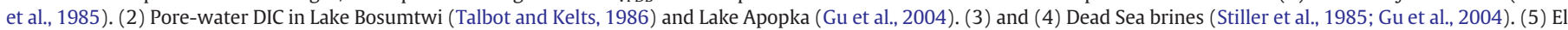

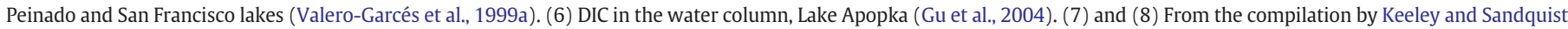
(2006).

covariance of Unit 1 ( 6 and $9 \delta$ units for carbon and oxygen, and $r=0.9$ in subunit 1a) show that Lake Chungará was shallower and smaller, which is consistent with the sedimentological data. Units 2 and 3 show smaller variability (near $6 \delta$ units for carbon and oxygen) and a weak and negative covariance ( $\mathrm{r}$ around -0.4 ). This negative covariance can be ascribed to the recycling of older carbon due to methanogenesis. Unit 4 (which corresponds to the 93L core samples) shows the narrower range of isotopic values along the lake evolution (around $5 \delta$ units) and a weak covariance $(r=0.36)$. The progressive decrease in the range may be due to the fact that Lake Chungará

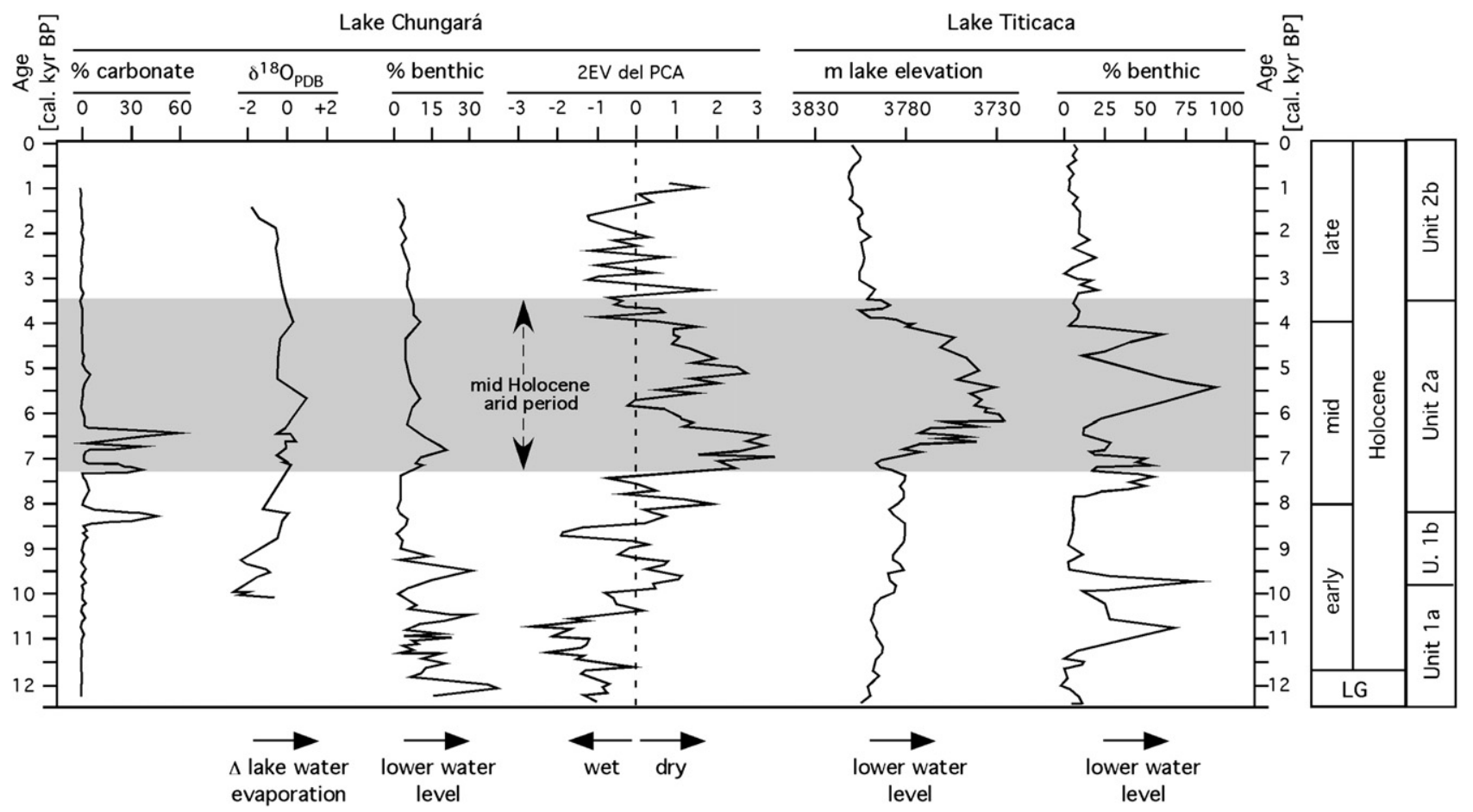

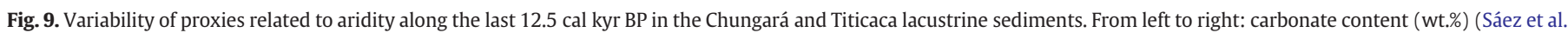

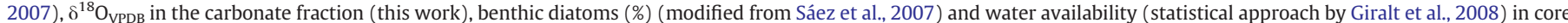

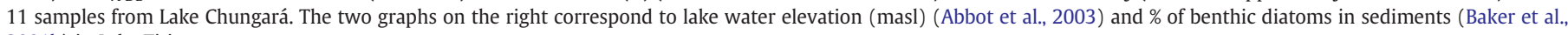
2001b) in Lake Titicaca. 
reached its highest level during the later evolutionary stages. The weak and positive covariance probably reflects the water inputs and evaporation in the shallow and coastal setting where core $93 \mathrm{~L}$ is placed.

\subsection{Mid-late Holocene paleoenvironmental changes from the carbonate record}

Core profile 11 combines low magnesium calcite crystals ('inorganic' carbonate) and ostracode low magnesium calcite valves (biogenic carbonate). In the absence of experimental data on the vital effects for Limnocythere $s p$ and in order to be able to combine the two carbonates, three samples in which both carbonates coexist were used to calculate the vital effects (Table 3 ). ${ }^{13} \mathrm{C}$ and ${ }^{18} \mathrm{O}$ relative enrichments of Limnocythere carbonate with respect to the coexisting inorganic carbonate was determined in -0.70 and $+0.90 \%$, respectively. Calcite endogenic crystals and ostracode valves (corrected for the vital effect) display similar isotopic values in the Lake Chungará offshore area (i.e. cores 11 and 14), reflecting the DIC- $\delta{ }^{13} C_{\mathrm{VPDB}}$ values (now around +4 to $+6 \%$; Table 1 ) in the lake waters. By contrast, bivalve remains vary considerably more because of greater vital effects and the inheritance of aquatic plants that are common in their diets (Keith et al., 1964). This prompted us to use the isotopic data from endogenic carbonate crystals and ostracode valves (corrected of vital effects) from core 11 to obtain the $\delta^{13} \mathrm{C}_{\mathrm{VPDB}}$ and $\delta^{18} \mathrm{O}_{\mathrm{VPDB}}$ vertical profiles of the carbonate fraction (Fig. 7). These profiles were used to characterise the environmental fluctuations of Lake Chungará over the last $10.2 \mathrm{kyr}$.

The early stages of carbonate precipitation through the upper part of subunit $1 \mathrm{a}$ and in the lower part of subunit $1 \mathrm{~b}$ (between 10.2 and $9.0 \mathrm{cal}$ kyr BP) vary considerably in the $\delta^{13} \mathrm{C}_{\mathrm{VPDB}}$ values, between +7 and $-2 \%$, and in $\delta^{18} \mathrm{O}_{\mathrm{VPDB}}$, from $-3 \%$ o to $0 \%$ (Figs. 7 and 9 ). This isotopic variability coincided with significant changes in the lake surface/volume ratio (Sáez et al., 2007). First, a flooding of extensive shallow areas of the eastern platform occurred (Hernández et al., 2008). The low $\delta^{18} \mathrm{O}_{\mathrm{VPDB}}$ values at these times (around -3\%) indicate that lake waters had scarcely evaporated. After the flooding, a major peak of benthic diatoms exceeded $40 \%$ between 10.0 and 9.6 cal kyr BP, indicating a shallow water environment. During this dry period, lake waters progressively evaporated, and an increase in photosynthetic activity related to the development of extraordinary diatom blooms (Bao et al., 2010) could have triggered the endogenic precipitation of carbonate crystals. Moreover, variations in seasonality giving rise to calcium inputs into the lake linked to short humid seasons during arid periods (such as the recent 'Bolivian or altiplanic winter' in the Andes due to changes in the location of the Bolivian High; Vuille, 1999) could have caused intermittent carbonate precipitation (Shapley et al., 2005).

Along the upper part of subunit $1 \mathrm{~b}$ and in the lower part of subunit 2a (between 9.0 and $7.5 \mathrm{cal}$ kyr BP), $\delta^{13} \mathrm{C}_{\mathrm{VPDB}}$ and $\delta^{18} \mathrm{O}_{\mathrm{VPDB}}$ vary less with higher values between +6 and $+2 \%$ and between -1 and $+1 \%$, respectively. Endogenic carbonate precipitation (mainly as low magnesium calcite crystals) increases significantly in this period, with a strong peak around $8.3 \mathrm{kyr}$ (Fig. 9), which matches the increases in both $\delta^{13} \mathrm{C}_{\mathrm{VPDB}}$ and $\delta^{18} \mathrm{O}_{\mathrm{VPDB}}$, indicating the evolution towards more evaporated lake waters.

Finally, in subunit 2a and in the lower part of subunit $2 \mathrm{~b}$ (between 7.0 and $1.5 \mathrm{cal} \mathrm{kyr} \mathrm{BP}) \delta^{13} \mathrm{C}_{\mathrm{VPDB}}$ values are stable and vary around $+4 \%$, and $\delta^{18} \mathrm{O}_{\mathrm{VPDB}}$ between +2 and $-1 \%$, respectively. The trend in subunit 2a towards higher $\delta^{18} \mathrm{O}_{\mathrm{VPDB}}$ values (Figs. 7 and 9 ) reflects the increase in evaporation (and salinity) and the reduction of the lake water volume and depth, coeval with the highest carbonate precipitation, between 8.3 and $6.4 \mathrm{cal} \mathrm{kyr}$ BP. The fact that higher $\delta^{18} \mathrm{O}_{\mathrm{VPDB}}$ values occurred during the middle and upper part of subunit $2 \mathrm{a}$ and the end of the main carbonate event seems to confirm this evolution: Between the onset of carbonate precipitation at $10.2 \mathrm{kyr}$ and the arrival of the mid-Holocene arid period at $7.3 \mathrm{kyr}$, carbonates show relatively low $\delta{ }^{18} \mathrm{O}_{\text {VPDB }}$ values. The $\delta^{18} \mathrm{O}_{\text {VPDB }}$, which increased in carbonates during the development of the arid event, shows that lake waters became more evaporated. In the uppermost carbonate sediments (subunit $2 \mathrm{~b}$ ) the trend reverses, around $6 \mathrm{cal} \mathrm{kyr} \mathrm{BP}$, to lower $\delta^{18} \mathrm{O}_{\mathrm{VPDB}}$ values with a drop around $2.2 \mathrm{cal} \mathrm{kyr} \mathrm{BP}$, which is interpreted as the final decrease in aridity (Figs. 7 and 9).

The increase of about $3 \%$ between the base of subunit $1 \mathrm{~b}$ and the centre of subunit $2 \mathrm{a}$ followed by a decline until reaching subunit $2 \mathrm{~b}$ should be interpreted as reflecting an arid period between 7.3 and 3.5 cal kyr BP, with an aridity maximum of around 6.0 cal kyr BP (Fig. 9). An arid period in the mid-Holocene has been suggested on the basis of high resolution XRF and mineralogical data (Moreno et al., 2007) and on the basis of water availability quantified using a statistical approach (Giralt et al., 2008). Furthermore, increases in benthic diatoms at 6.9 (20\%), 5.7 (10\%) and $4.1 \mathrm{cal} \mathrm{kyr} \mathrm{BP} \mathrm{(Fig.} \mathrm{9)} \mathrm{reflect} \mathrm{shallower} \mathrm{periods}$ along the evolution of the Chungará paleolake (Sáez et al., 2007). This arid period is coeval with the aridity crisis observed in other paleoclimatic records of the Altiplano (Paco Cocha and Titicaca lakes, Abbot et al., 2003; Tapia et al., 2003; and Salar de Uyuni, Baker et al., 2001a) (Fig. 9).

\section{Conclusions}

Both the sedimentary record and the isotopic markers indicate that phytoplankton is the main source of organic matter in the offshore sediments of Lake Chungará. Lower Unit 1 (12.3 to 8.3 cal kyr $\mathrm{BP}$ ) is a diatomaceous ooze and the upper Unit 2 (8.3 cal kyr BP to present) is a diatomaceous sediment interbedded with volcanic tufa. Phytoplankton, macrophytes and, to a lesser extent, land plants are the main organic contributions to the littoral sediments.

TOC $-\delta^{13} \mathrm{C}_{\mathrm{VPDB}}$ values reflect the organic provenance (phytoplankton vs. macrophytes and land plants) and changes in productivity. The increase in $\mathrm{TN}-\delta^{15} \mathrm{~N}_{\mathrm{AIR}}$ in the early stages of lake evolution reflects the increase in aquatic productivity. Changes in TOC along the sedimentary record provide evidence of the increase in biological productivity and in the macrophytic contribution. Low values of $\delta^{15} \mathrm{~N}_{\text {AIR }}$ around $0 \%$ in the lowermost lacustrine sediments are probably due to the dominance of cyanobacterial biomass.

Carbonate content in the Lake Chungará sediments is commonly below $1 \mathrm{wt}$.\% but is higher in the upper part of subunit $1 \mathrm{~b}$ and the lower part of subunit 2a. In addition to its presence as bioclasts (small molluscs and ostracodes), carbonates consist of endogenic calcite (or aragonite) crystals arranged as cm-thick levels. Seasonal $\mathrm{CO}_{2}$ photosynthetic depletions of lake water DIC may have been responsible for the mmthick carbonate layer deposition. The long-term carbonate deposition seems to be controlled by changes in seasonality.

Euhedral to subhedral calcite and aragonite crystals and spheroids, micrometric in size, are the most common shapes. Many crystal shapes are similar to those obtained by induced precipitation in gels or exopolysaccharide and proteinic matrix, suggesting similar processes in the sediments of Lake Chungará that account for the coexistence of calcite crystals and aragonite spherules. The presence of calcite vs. aragonite has been attributed to the $\mathrm{Mg} / \mathrm{Ca}$ ratio in the water and to the precipitation in an organic matrix. Lateral changes in mineralogy (calcite crystals vs. aragonite needles) detected at the same level in locations at a distance of some $\mathrm{km}$ were ascribed to contemporary (or quasicontemporary) chemical changes in the water inputs into the lake.

$\delta^{13} \mathrm{C}_{\mathrm{VPDB}}$ in endogenic carbonate crystals and ostracode valves increased while $\delta^{18} \mathrm{O}_{\mathrm{VPDB}}$ decreased from basin to shore, reflecting the relative contribution of the organic producers (phytoplankton and macrophytes), the DIC inputs, and the residence time. The $\delta^{18} \mathrm{O}_{\mathrm{VPDB}}$ depends on the isotopic composition of water inputs into the lake and its water balance. The variations and covariation of $\delta^{13} \mathrm{C}_{\mathrm{VPDB}}$ and $\delta^{18} \mathrm{O}_{\text {VPDB }}$ indicate that the lake was shallower in the early stages of its evolution and that the water level and volume increased with time. Bacterial methanogenesis in the bottom sediment gave rise to carbonate cements with very high $\delta^{13} C_{\mathrm{VPDB}}$ values. Heavy carbon 
advection to the water column is with $\mathrm{DIC}$ speciation $\left(\mathrm{HCO}_{3}^{-}\right.$ dominant at $\mathrm{pH}$ around 9) responsible for the high $\delta^{13} \mathrm{C}_{\mathrm{VPDB}}$ values (around 15\% higher than commonly reported values) in the whole carbon reservoirs of Lake Chungará.

Lake Chungará underwent major changes between the onset of the Holocene and around $9.6 \mathrm{cal}$ kyr BP, which is evidenced by an overall increase in TOC, TN, and TN- $\delta{ }^{15} \mathrm{~N}_{\mathrm{AIR}}$ as well as by fluctuating values of TOC- $\delta{ }^{13} C_{\text {VPDB }}$. These changes were probably linked to major shifts in the lake surface/volume ratio, associated with the rise and fall in lake level. A pulse of aridity at around $10 \mathrm{kyr}$ BP in addition to the increased calcium content in the lake water favoured the onset of carbonate precipitation. $\delta^{18} \mathrm{O}_{\mathrm{VPDB}}$ values in ostracode valves and endogenic carbonate crystals, combined with other proxies (benthic/planktonic diatoms ratio, water availability inferred from the statistical treatment of magnetic susceptibility and geochemical data) demonstrate an arid period in the midHolocene, between 7.3 and 3.5 kyr B.P, and an aridity maximum around 6.0 kyr BP.

\section{Acknowledgements}

This work has been funded by the Spanish Ministry of Science and Education through the projects: ANDESTER (BTE2001-3225), LAVOLTER (CGL2004-00683/BTE) and GEOBILA (CGL2007, 60932/BTE), and by the Catalan Autonomous Government through the 2009SGR1451 project. A. Moreno also acknowledges the funding from the Marie Curie fellowship, OIF proposal 021673. We are also indebted to the Scientific-Technical Survey of the Barcelona University for their help in XRD determinations, SEM-EDS observations and stable isotopic analyses $\left(\delta D_{\text {VSMOW }}\right.$ and $\delta^{18} \mathrm{O}_{\text {VSMOW }}$ in water samples, $\delta^{13} C_{\text {VPDB }}$ and $\delta^{15} \mathrm{~N}_{\mathrm{AIR}}$ in bulk organic fraction, and $\delta^{13} \mathrm{C}_{\mathrm{VPDB}}$ and $\delta^{18} \mathrm{O}_{\mathrm{VPDB}}$ in carbonates) and to the Estación Experimental Aula Dei (CSIC) where TOC and TN determinations were performed. The original manuscript has been improved by two anonymous referees and the editor.

\section{References}

Abbot, M.B., Wolfe, B.B., Wolfe, A.P., Seltzer, G.O., Aravena, R., Mark, B.G., Polissar, P.J., Rodbell, D.T., Rowe, H.D., Vuille, M., 2003. Holocene paleohydrology and glacial history of the central Andes using multiproxy lake sediment studies. Palaeogeography, Palaeoclimatology, Palaeoecology 194, 123-138.

Aravena, R., Susuki, O., Peña, H., Pollastri, A., Fuenzalida, H., Grilli, A., 1999. Isotopic composition and origin of the precipitation in Northern Chile. Applied Geochemistry $14,411-422$.

Bade, D.L., Carpenter, S.R., Cole, J.J., Hanson, P.C., Hesslein, R.H., 2004. Controls of $\delta^{13}$ CDIC in lakes: geochemistry, lake metabolism and morphometry. Limnology and Oceanography 49, 1160-1172.

Baker, P., Rigsby, C., Seltzer, G., Fritz, S., Lowenstein, T., Bacher, N., Veliz, C., 2001a. Tropical climate changes at millennial and orbital timescales on the Bolivian Altiplano. Nature 409, 698-701.

Baker, P.A., Seltzer, G.O., Fritz, S.C., Dunbar, R.B., Grove, M.J., Tapia, P.M., Cross, S.L., Rowe, H.D., Broda, J.P., 2001b. The history of South American tropical precipitation for the past 25000 years. Science 291, 640-643.

Bao, R., Sáez, A., Servant-Vildary, S., Cabrera, L., 1999. Lake-level and salinity reconstruction from diatom analyses in Quillagua formation (late Neogene, Central Andean Forearc, northern Chile). Palaeogeography, Palaeoclimatology, Palaeoecology $153,309-335$.

Bao, R., Hernández, A., Sáez, A., Prego, R., Giralt, S., Moreno, A., Pueyo, J.J., Valero-Garcés, B., 2010. Climate and lake morphometry controls on biosiliceous productivity in lake Chungará, Northern Chile, during the last $12400 \mathrm{cal}$. yr BP. The Meeting of the Americas, 8-13 August 2010. Foz de Iguazu, Brasil. Abstract.

Barkan, E., Luz, B., Lazar, B., 2001. Dynamics of the carbon dioxide system in the Dead Sea. Geochimica et Cosmochimica Acta 65, 355-368.

Bischoff, J.L., Fyfe, W.S., 1968. Catalysis, inhibition and the calcite-aragonite problem: I. The aragonite-calcite transformation. American Journal of Science 266, 65-79.

Braissant, O., Cailleau, G., Dupraz, C., Verrecchia, E., 2003. Bacterially induced mineralizacion of calcium carbonate in terrestrial environments: the role of exopolysaccharides and amino acids. Journal of Sedimentary Research 73, 485-490.

Brenner, M., Whitmore, T.J., Curtis, J.H., Hodell, D.A., Schelske, C.L., 1999. Stable isotope $\delta^{13} \mathrm{C}$ and $\delta^{15} \mathrm{~N}$ signatures and sedimented organic matter as indicators of historic lake trophic state. Journal of Paleolimnology 22, 205-221.

Callame, B., Dupuis, J., 1972. Sur la precipitation d'aragonite à partir des eaux interstitielles des sols littoraux et des formations sableuses intertidales de la Pointe d'Arçay (Vendée). Comptes Rendus de l'Académie des Sciences de Paris 274 (serieD), 675-677.
Chung, F., 1974. Quantitative interpretation of X-ray diffraction patterns of mixtures: II. Adiabatic principles of X-ray diffraction analysis of mixtures. Journal of Applied Crystallography 7, 526-531.

Défarge, C., Trichet, J., Jaunet, A.M., Robert, M., Tribble, J., Sansone, F.J., 1996. Texture of microbial sediments revealed by cryo-scanning electron microscopy. Journal of Sedimentary Research 66, 935-947.

Deuser, W.G., Degens, E.T., 1967. Carbon isotope fractionation in the system $\mathrm{CO}_{2}$ (gas)$\mathrm{CO}_{2}$ (aqueous) $-\mathrm{HCO}_{3}^{-}$(aqueous). Nature 215, 1033-1035.

Dorador, C., Pardo, R., Vila, I., 2003. Variaciones temporales de parámetros físicos químicos y biológicos de un lago de altura: el caso del lago Chungará. Revista Chilena de Historia Natural 76, 15-22.

Fernández-Díaz, L., Putnis, A., Prieto, N., Putnis, C., 1996. The role of magnesium in the crystallization of calcite and aragonite in a porous medium. Journal of Sedimentary Research 66, 482-491.

Fritz, S.C., Baker, P.A., Tapia, P., Garland, J., 2006. Spatial and temporal variation in cores from Lake Titicaca, Bolivia/Peru during the last 13000 yrs. Quaternary International $158,23-29$

Gibert, R., Taberner, C., Sáez, A., Giralt, S., Alonso, R.N., Edwards, R.L., Pueyo, J.J., 2008. Igneous origin of $\mathrm{CO}_{2}$ in ancient and recent hot-spring waters and travertines from the Argentinean Andes. Journal of Sedimentary Research 79, 554-567.

Giralt, S., Julia, R., Klerkx, J., 2001. Microbial biscuits of vaterite in lake Issyk-Kul (Republic of Kyrgyzstan). Journal of Sedimentary Research 71, 430-435.

Giralt, S., Moreno, A., Bao, R., Sáez, A., Prego, R., Valero-Garcés, B.L., Pueyo, J.J., GonzálezSampériz, P., Taberner, C., 2008. A statistical approach to disentangle environmental forcings in a lacustrine record: the Lago Chungará case (Chilean Altiplano). Journal of Paleolimnology 40, 195-215.

González-Muñoz, M.T., Ben Chekroun, K., Ben Aboud, A., Arias, J.M., Rodriguez-Gallego, $\mathrm{M} ., 2000$. Bacterially induced $\mathrm{Mg}$-calcite formation: role of $\mathrm{Mg}^{2+}$ in development of crystal morphology. Journal of Sedimentary Research 70, 559-564.

Grosjean, M., 1994. Paleohydrology of the Laguna Lejía (north Chilean Altiplano) and climatic implications for late-glacial times. Palaeogeography, Palaeoclimatology, Palaeoecology 109, 89-100.

Grosjean, M., Valero-Garcés, B.L., Geyh, M.A., Messerli, B., Schreier, H., Kelts, K., 1997. Mid and Late Holocene limnogeology of Laguna del Negro Francisco, northern Chile, and its paleoclimatic implications. Holocene 7, 151-159.

Grosjean, M., van Leeuwen, J.F., van der Knaap, W., Geyh, M.A., Ammann, B., Tañer, W., Messerli, B., Núñez, L., Valero-Garcés, B.L., Veit, H., 2001. A $22000{ }^{14} \mathrm{C}$ years B.P. sediment and pollen record of climate change from Laguna Miscanti ( $\left.23^{\circ} \mathrm{S}\right)$, northern Chile. Global Planetary Change 28, 35-51.

Gu, B., Schelske, C.L., 1996. Temporal and spatial variations in phytoplankton carbon isotopes in a polimictic subtropical lake. Journal of Plankton Research 18 2081-2092.

Gu, B., Schelske, C.L., Hodell, D.A., 2004. Extreme $13 \mathrm{C}$ enrichments in a shallow hypereutrophic lake: implications for carbon cycling. Limnology and Oceanography 49, 1152-1159.

Hassan, K.M., Swinehart, J.B., Spalding, R.F., 1997. Evidence for Holocene environmental change from $\mathrm{C} / \mathrm{N}$ ratio, and $\delta 13 \mathrm{C}$ and $\delta 15 \mathrm{~N}$ values in Swan Lake sediments, western Sand Hills, Nebraska. Journal of Paleolimnology 18, 121-130.

Heegaard, E., Birks, H., Telford, R., 2005. Relationships between calibrated ages and depth in stratigraphical sequences: an estimation procedure by mixed-effect regression. Holocene 15, 612-618.

Hernández, A., Bao, R., Giralt, S., Leng, M., Barker, P.A., Sáez, A., Pueyo, J.J., Moreno A., Valero-Garcés, B.L., Sloane, H.J., 2008. The palaeohydrological evolution of Lago Chungará (Andean altiplano, northern Chile) during Late Glacial-Early Holocene using oxygen isotopes in diatom silica. Journal of Quaternary Science 23, 351-363.

Hernández, A., Giralt, S., Bao, R., Sáez, A., Leng, M.J., Barker, P.A., 2010. ENSO and solar activity signals from oxygen isotopes in diatom silica during Lateglacial-Holocene transition in Central Andes (18ㅇ). Journal of Paleolimnology 44, 413-429.

Herrera, C., Pueyo, J.J., Sáez, A., Valero-Garcés, B.L., 2006. Relación de aguas superficiales y subterráneas en el area del Lago Chungará y lagunas de Cotacotani, norte de Chile: un estudio isotópico. Revista Geológica de Chile 33, 299-325.

Hollander, D.J., McKenzie, J.A., 1991. $\mathrm{CO}_{2}$ control on carbon isotope fractionation during aqueous photosynthesis: a paleo-pCO 2 barometer. Geology 19, 929-932.

Hora, J.M., Singer, B.S., Wörner, G., 2007. Volcano evolution and eruptive flux on the thick crust of the Andean Central Volcanic zone: 40Ar/39Ar constraints from Volcán Parinacota, Chile. Geological Society of America Bulletin 119, 343-362.

Ito, E., 2001. Application of stable isotope techniques to inorganic and biogenic carbonates. In: Last, W.M., Smol, J.P. (Eds.), Tracking environmental change using lake sediments. : Physical and geochemical methods, Vol. 2. Kluber Academic Publishers, pp. 351-371.

Jiménez-López, C., Rodríguez-Navarro, A., Domínguez-Vera, J.M., García-Ruiz, J.M., 2003. Influence of lysozyme on the precipitation of calcium carbonate. Geochimica et Cosmochimica Acta 67, 1667-1676.

Julià, R., Burjacs, F., Dasí, M.J., Mezquita, F., Miracle, M.R., Roca, J.R., Seret, G., Vicente, E 1998. Meromixis origin and recent trophic evolution in the Spanish mountain lake La Cruz. Aquatic Sciences 60, 279-299.

Keeley, J.E., Sandquist, D.R., 2006. Carbon: freshwater plants. Plant, Cell \& Environment 15, 1021-1035.

Keith, M.L., Anderson, G.M., Eichler, R., 1964. Carbon and oxygen isotopic composition of mollusc shells from marine and fresh-water environments. Geochimica et Cosmochimica Acta 28, 1757-1786.

Lehmann, M.F., Bernasconi, S.M., Barbieri, A., McKenzie, A., 2002. Preservation of organic matter and alteration of its carbon and nitrogen isotope composition during simulated and in situ early sedimentary diagenesis. Geochimica et Cosmochimica Acta 66, 3573-3584. 
Leng, M.J., Lamb, A.L., Heaton, T.H.E., Marshall, J.D., Wolfe, B.B., Jones, M.D., Holmes, J.A., Arrowsmith, C., 2005. Isotopes in lake sediments. In: Leng, M.J. (Ed.), Isotopes in Palaeoenvironmental Research. Springer, pp. 147-184.

Li, H.C., Ku, T.L., 1997. d13C-d180 covariance as a paleohydrological indicator for closed basin lakes. Palaeogeography, Palaeoclimatology, Palaeoecology 133, 69-80.

Lowenstam, H.A., 1955. Aragonite needles secreted by algae and some sedimentary implications. Journal of Sedimentary Petrology 25, 270-272.

Lowenstam, H.A., Epstein, S., 1956. On the origin of sedimentary aragonite needles of the Great Bahama Bank. Publications of the Division of the Geological Sciences, California Institute of Technology, 810, pp. 365-375.

Ma, T.S., Gutterson, M., 1970. Organic elemental analysis. Analytical Chemistry 42 , 105-114.

Macintyre, I.G., Reid, R.P., 1992. Comment on the origin of aragonite needle mud: a picture is worth a thousand words. Journal of Sedimentary Petrology 62, 1095-1097.

McKenzie, J.A., 1985. Carbon isotopes and productivity in the lacustrine and marine environment. In: Stumm, W. (Ed.), Chemical processes in lakes. Wiley, New York, pp. 99-118.

Meyers, P.A., 1994. Preservation of source identification of sedimentary organic matter during and after deposition. Chemical Geology 144, 289-302.

Meyers, P.A., 1997. Organic geochemical proxies of paleoceanographic, paleolimnologic and paleoclimatic processes. Organic Geochemistry 27, 213-250.

Meyers, P.A., 2003. Applications of organic geochemistry to paleolimnological reconstructions. Organic Geochemistry 34, 261-289.

Meyers, P.A., Teranes, J.L., 2001. Sediment organic matter. In: Last, W.M., Smol, J.P. (Eds.), Tracking environmental change using lake sediments. : Physical and geochemical methods, Vol. 2. Kluber Academic Publishers, pp. 239-270.

Mladinic, P., Hrepic, N., Quintana, E., 1987. Water physical and chemical characterization of the lakes Chungará and Cotacotani. Archivos de Biología y Medicina Experimentales 20, 89-94.

Monaghan, P.H., Lytle, M.L., 1956. The origin of calcareous ooliths. Journal of Sedimentary Petrology 26, 111-118.

Moreno, A., Giralt, S., Valero-Garcés, B.L., Sáez, A., Bao, R., Prego, R., Pueyo, J.J., GonzálezSampériz, P., Taberner, C., 2007. A 14 kyr record from the tropical Andes: the Lago Chungará sequence $\left(18^{\circ} \mathrm{S}\right.$, northern Chilean Altiplano). Quaternary International $161,4-21$.

Mühlhauser, H.A., Hrepic, N., Mladinic, P., Montecino, V., Cabrera, S., 1995. Water quality and limnological features of the Andean Lake Chungará, northern Chile. Revista Chilena de Historia Natural 68, 341-349.

Müller, G., Irion, G., Förstner, U., 1972. Formation and diagenesis of inorganic Ca-Mg carbonates in the lacustrine environment. Naturwissenschaften 59, 158-164.

Nelson, C.S., Smith, A.M., 1966. Stable oxygen and carbon isotope compositional fields for skeletal and diagenetic components in New Zealand Cenozoic non-tropica carbonate sediments and limestones: a synthesis and review. New Zealand Journa of Geology and Geophysics 39, 93-107.

Oppenheimer, C.H., 1961. Note on the formation of spherical aragonitic bodies in the presence of bacteria from the Bahama Bank. Geochimica and Cosmochimica Acta 23, 295-299.

Pedone, V.A., Folk, R.L., 1996. Formation of aragonite cement by nannobacteria in the Great Salt Lake, Utah. Geology 24, 763-765.

Reimer, P.J., Baillie, M.G.L., Bard, E., Bayliss, A., Beck, J.W., Bertrand, C.J.H., Blackwell, P.G., Buck, C.E., Burr, G.S., Cutler, K.B., Damon, P.E., Edwards, R.L., Fairbanks, R.G., Friedrich, M., Guilderson, T.P., Hogg, A.G., Hughen, K.A., Kromer, B., McCormac, F.G., Manning, S.W., Ramsey, C.B., Reimer, R.W., Remmele, S., Southon, J.R., Stuiver, M., Talamo, S., Taylor, F.W., van der Plicht, J., Weyhenmeyer, C.E., 2004. IntCal04 terrestrial radiocarbon age calibration, 26-0 ka BP. Radiocarbon 46, 1029-1058.

Risacher, F., Alonso, H., Salazar, C., 1999. Geoquímica de aguas en cuencas cerradas: I, II, III Regiones, Chile. Ministerio de Obras Públicas, 1. 209 pp., Chile.

Robbins, L.L., Blackwelder, P.L., 1992. Biochemical and ultrastructural evidence for the origin of whitings: a biologically induced carbonate precipitation mechanism. Geology 20, 464-468.

Romero, L., Camacho, A., Vicente, E., Miracle, M.R., 2006. Sedimentation patterns of photosynthetic bacteria based on pigment markers in meromictic Lake La Cruz (Spain): paleolimnological implications. Journal of Paleolimnology 35, 167-177.

Sáez, A., Cabrera, L., Jensen, A., Chong, G., 1999. Late Neogene lacustrine record and paleogeography in the Quillagua-Llamara basin, Central Andean fore-arc (Northern Chile). Palaeogeology, Palaeoclimatology, Palaeoecology 151, 5-37.

Sáez, A. Valero-Garcés, B.L., Moreno, A., Bao, R., Pueyo, J.J., González-Sampériz, P., Giralt, S., Taberner, C., Herrera, C., Gibert, R.O., 2007. Lacustrine sedimentation in active volcanic settings: the Late Quaternary depositional evolution of Lake Chungará (northern Chile). Sedimentology 54, 1191-1222.

Schelske, C.L., Hodell, D.A., 1995. Using carbon isotopes of bulk sedimentary organic matter to reconstruct the history of nutrient loading and eutrophication in Lake Erie. Limnology and Oceanography 40, 918-929.

Schwalb, A. 2003. Lacustrine ostracodes as stable isotope recorders of late-glacial and holocene environmental dynamics and climate. Journal of Paleolimnology 29, 267-351.

Schwalb, A., Burns, S.J., Kelts, K., 1999. Holocene environments from stable isotope stratigraphy of ostracodes and authigenic carbonate in Chilean Altiplano lakes. Palaeogeography, Palaeoclimatology, Palaeoecology 148, 153-168.
Servant-Vildary, S., Roux, M., 1990. Multivariate analysis of diatoms and water chemistry in Bolivian saline lakes. Hydrobiologia 197, 267-290.

Shapley, M.D., Ito, E., Donovan, J.J., 2005. Authigenic calcium carbonate flux in groundwater-controlled lakes: implications for lacustrine paleoclimatic records. Geochimica et Cosmochimica Acta 69, 2517-2533.

Sifeddine, A., Wirrmann, D., Albuquerque, A.L.S., Turcq, B., Cordeiro, R.C., Gurgel, M.H.C., Abrao, J.J., 2004. Bulk composition of sedimentary organic matter used in paleoenvironmental reconstructions: examples from the tropical belt of South America and Africa. Palaeogeography, Palaeoclimatology, Palaeoecology 214, 41-53.

Stiller, M., Rounick, J.S., Shasha, S., 1985. Extreme carbon-isotope enrichments in evaporite brines. Nature 316, 434-435.

Stuiver, M., Reimer, P.J., Bard, E., Beck, J.W., Burr, G.S., Hughen, K.A., Kromer, B., McCormac, F.G., van der Plicht, J., Spurk, M., 1998. INTCAL98 radiocarbon age calibration 24,000-0 cal BP. Radiocarbon 40, 1041-1083.

Suess, E., Fütterer, D., 1972. Aragonite ooids: experimental precipitation from seawater in the presence of humic acid. Sedimentology 19, 129-139.

Sylvestre, F., 2002. A high-resolution diatom reconstruction between 21,000 and 17,400 $14 \mathrm{C}$ yr BP from the southern Bolivian Altiplano $\left(18-23^{\circ} \mathrm{S}\right)$. Journal of Paleolimnology $27,45-57$.

Talbot, M.R., 1990. A review of the palaeohydrological interpretation of carbon and oxygen isotopic ratios in primary lacustrine carbonates. Chemical Geology (Isotope Geoscience Section) 80, 261-279.

Talbot, M.R., Kelts, K., 1986. Primary and diagenetic carbonates in the anoxic sediments of Lake Bosumtwi, Ghana. Geology 14, 912-916.

Talbot, M.R., Kelts, K., 1990. Paleolimnological signatures from carbon and oxygen isotopic ratios in carbonates from organic carbon-rich lacustrine sediments. In: Katz, B.J. (Ed.), Lacustrine basin exploration - case studies and modern analogues: A.A.P.G. Memoir, 50, pp. 99-112.

Tapia, P.M., Fritz, S.C., Baker, P.A., Seltzer, G.O., Dumbar, R.B., 2003. A Late Quaternary diatom record of tropical climate history from Lake Titicaca (Perú and Bolivia). Palaeogeography, Palaeoclimatology, Palaeoecology 194, 139-164.

Theissen, K.M., Dunbar, R.B., Rowe, H.D., Mucciarone, D.A., 2008. Multidecadal- to century-scale arid episodes on the northern Altiplano during the middle Holocene. Palaeogeography, Palaeoclimatology, Palaeoecology 257, 361-376.

Thompson, J.B., Schultze-Lam, S., Beveridge, T.J., Des Marais, D.J., 1997. Whiting events: biogenic origin due to the photosynthetic activity of cyanobacterial picoplankton. Limnology and Oceanography 42, 133-141.

Turner, J.V., Fritz, P., 1983. Enriched ${ }^{13} \mathrm{C}$ composition of interstitial waters in sediments of a freshwater lake. Canadian Journal of Earth Sciences 20, 616-621.

Utrilla, R., Vazquez, A., Anadón, P., 1998. Paleohydrology of the Upper Miocene Bicorb Lake (eastern Spain) as inferred from stable isotopic data from inorganic carbonates. Sedimentary Geology 121, 191-206.

Valero-Garcés, B.L., Delgado-Huertas, A., Ratto, N., Navas, A., 1999a. Large ${ }^{13} \mathrm{C}$ enrichment in primary carbonates from Andean altiplano lakes, northwest Argentina. Earth and Planetary Science Letters 171, 253-266.

Valero-Garcés, B.L., Grosjean, M., Kelts, K., Schreier, H., Messerli, B., 1999b. Holocene lacustrine deposition in the Atacama altiplano: facies models, climate and tectonic forcing. Palaeogeography, Palaeoclimatology, Palaeoecology 151, 101-125.

Valero-Garcés, B.L., Grosjean, M., Messerli, B., Schwalb, A., Kelts, K., 2000. Late Quaternary lacustrine deposition in the Chilean Altiplano $\left(18^{\circ}-28^{\circ} \mathrm{S}\right)$. In: Gierlowski-Kodersch, E.H., Kelts, K. (Eds.), Lake basins through space and time: American Association of Petroleum Geologists, Studies in Geology, 46, pp. 625-639.

Valero-Garcés, B.L., Delgado-Huertas, A., Navas, A., Edwards, L., Schwalb, A., Ratto, N. 2003. Patterns of regional hydrological variability in central-southern altiplano $\left(18^{\circ}-26^{\circ} \mathrm{S}\right)$ lakes during the last 500 years. Palaeogeography, Palaeoclimatology, Palaeoecology 194, 319-338.

von Grafenstein, U., Erlernkeuser, H., Trimborn, P., 1999. Oxygen and carbon isotopes in modern fresh-water ostracods valves: assessing vital offsets and autoecological effects of interest from paleoclimate studies. Palaeogeography, Palaeoclimatology, Palaeoecology 148, 133-152.

Vuille, M., 1999. Atmospheric circulation over the Bolivian Altiplano during dry and wet periods and extreme phases of the Southern Oscillation. International Journal of Climatology 19, 1579-1600.

Wu, S, Ma, B., Zeng, F. Chen, J. Zhao, J. Tong Z, Luo, Y, 2008. Spherulite formation of lipophilic surfactant induced by noncrystalline amphiphilic diblock copolymer. Crystal Growth \& Design 8, 4589-4595.

Wu, Y., Li, S., Lücke, A., Wünnemann, B., Zhou, L., Reimer, P., Wang, S., 2010. Lacustrine radiocarbon reservoir ages in Co Ngoin and Zigê Tangco, central Tibetan plateau. Quaternary International 212, 21-25.

Xiang, J., Cao, H., Warner, J.H., Watt, A.A.R., 2008. Crystallization and self-assembly of calcium carbonate architectures. Crystal Growth \& Design 8, 4583-4588.

Zhou, G., Zheng, Y., 2003. An experimental study of oxygen isotope fractionation between inorganically precipitated aragonite and water at low temperatures. Geochimica et Cosmochimica Acta 67, 387-399. 